\title{
Oil and Conflict: What Does the Cross-Country Evidence Really Show?*
}

\author{
Anca M. Cotet ${ }^{\dagger}$ and Kevin K. Tsui ${ }^{\ddagger}$ \\ Ball State University and Clemson University
}

February 2010

\begin{abstract}
This paper examines the effect of oil abundance on political violence. First, we revisit one of the main empirical findings of the civil conflict literature that oil abundance causes civil war. Using a unique panel dataset describing worldwide oil discoveries and extractions, we show that simply controlling for country fixed effects removes the statistical association between oil reserves and civil war in a sample of more than 100 countries over the period 1930-2003. Other macropolitical violence measures, such as coup attempts and irregular leader transitions, are not affected by oil reserves either. Rather, we find that oil-rich nondemocratic countries have a larger defense burden. To further address the problems of endogeneity and measurement error, we exploit randomness in the success or failure of oil explorations. We find that oil discoveries do not increase the likelihood of violent challenges to the state in the sample of country-years in which at least one exploratory well is drilled, and oil discoveries increase military spending in the subsample of nondemocratic countries. Similar results are obtained on a larger sample which includes country-years without oil exploration while controlling for selection based on the likelihood of exploration using propensity score matching. We suggest a possible explanation for our findings based on the idea that oil-rich nondemocratic regimes effectively expend resources to deter potential challengers.
\end{abstract}

JEL Classifications: H56, Q34

\footnotetext{
* The title of this paper parallels Rajan and Subramanian's (2008) "Aid and Growth: What Does the Cross-Country Evidence Really Show?" A previous version circulated under the title "Oil and Conflict: Evidence from Oil Explorations and Discoveries." Support Special thanks to Colin Campbell from the Association for the Study of Peak Oil and Fredrik Robelius for providing access to some of the data and institutional details of the oil industry. We would also like to thank Bill Dougan, John Lott, Rachel Ngai, Chris Rohlfs, Patrick Warren, and seminar participants at the Ball State Univerity and Clemson University for helpful comments and discussions. All remaining errors are ours.

${ }^{\dagger}$ Department of Economics, Ball State University. Whitinger Business Building, Room 201, 2000 W. University Ave., Muncie, IN 47306. Email: amcotet@ bsu.edu

* The John E. Walker Department of Economics, Clemson University. 222 Sirrine Hall, Clemson, SC 29634. Email: ktsui@clemson.edu
} 


\section{Introduction}

The conventional wisdom dating back to at least Malthus's time is that resource scarcity triggers conflict. Since the end of the Cold War, however, having an abundance of natural resources, particularly oil, has been blamed for many civil wars and coup attempts in developing countries and for political instability in the Middle East. If civil warfare is caused by shortage and poverty, how can lucrative oil "fuel" separatism and cause political violence and instability? This puzzle is exacerbated by another popular argument for the curse of oil - oil wealth enhances stability and durability of bad authoritarian regimes because it enables dictators to become stronger by funding patronage and repressive apparatuses. For instance, how do we reconcile the coexistence of some unusually durable regimes, such as those of Iraq's Saddam Hussein, Indonesia's Suharto, and Saudi Arabia's royal family, and the high incidence of civil conflict and coup attempts in some other oil-rich countries like Angola, Chad, and Nigeria, where distribution of the oil rent is believed to contribute to violence and separatist tendencies?

This paper uses data on worldwide oil endowment and activities to provide new evidence of the effect of oil abundance on political violence. In particular, we re-examine the oil-fuels-war hypothesis and provide the first systematic analysis of the impact of oil abundance on coup attempts, irregular leader transitions, and military spending using a unique industrial dataset describing worldwide oil explorations, discoveries, extractions, and endowment.

Existing macro-level studies of the oil-fuels-war hypothesis establish a cross-country correlation between oil dependence (measured by flow variables such as share of fuel exports in a country's GDP, oil production rate or oil rent per capita) and onset of civil war, but do not typically control for factors that simultaneously affect both variables. The endogeneity of the rate of oil extraction is troubling because it can bias the studies based on simple pooled OLS estimation in any direction. First, unfavorable institution, such as weak property rights, can reduce extraction rates (Bohn and Deacon, 2000), and such unfavorable institution may be more prone to civil conflict. Moreover, there is a concern of reverse causality because armed conflict could directly damage oil production process. These omitted variable and endogeneity problems tend to bias the oil impact on conflict downward. However, the "tragedy of commons" suggests 
that countries with incomplete property rights are likely to overuse resource stocks. In addition, when leaders over-extract relative to the efficient extraction path in a politically unstable environment because they heavily discount the future (Robinson, Torvik, and Verdier, 2006), simple pooled OLS estimates can also exaggerate the effect of oil on political violence. ${ }^{1}$ As a stock variable, oil reserves are less likely to be subject to this endogeneity bias. Indeed, oil wealth, being the capital value of future oil rents, is better proxied by oil reserves than by oil production, since the production profile of each oilfield follows an inverted U-shaped pattern over time because of geological constraints. Furthermore, the production rate also understates the oil wealth of the swing producers who produce below their full capacity.

We utilize two strategies to investigate the causal effect of oil abundance on countrylevel political violence that potentially leads to regime turnover. First, to facilitate a comparison between our results and previous findings, we construct a long panel of oil abundance (over the 1930-2003 period) based on industrial data, where oil abundance is measured by the stock of oil reserves instead of other flow measures. Such a long panel dataset enables us to take advantage of the within-country variation in oil abundance because global oil discovery peaked in the 1960s. Consistent with most previous findings, we find that larger oil reserves are statistically associated with a higher likelihood of the onset of civil war in a simple pooled cross-country time-series setting. However, once controlling for other possible country-specific omitted factors that do not vary over time (such as rough terrain that favors insurgency, or a culture of violence) by including country fixed effects, this statistical association between oil abundance and civil war onset disappears. We show that the lack of a significant relationship between oil reserves and civil war is not driven by large standard errors which may be due to measurement error, a common concern using fixed-effects estimations, and hence it sheds considerable doubt on previous researchers' claim that oil has a robust causal effect on civil war onset.

This lack of relationship is robust to various ways to measure oil abundance and political violence. First, although oil wealth is a stock variable, the appropriable oil wealth depends also

\footnotetext{
${ }^{1}$ The recent international finance literature also shows that financial crises, which sometimes may trigger political instability, accelerate the production of exhaustible resources among heavily indebted developing countries because these crises increase the shadow cost of capital and tighten the government budget constraint (Brown et al., 2009). Over-extraction can also occur to finance military spending during war time. For example, Brown et al. (2009) document that the U.S. dramatically expanded copper and iron ore production during the two world wars. Oil rent is also endogenous to conflict when conflict occurs in major oil-exporter which leads to oil price shock.
} 
on the political leader's expected tenure in office. For myopic leaders who care only about current oil rent, the stream of oil revenue in distant future is irrelevant. Replacing oil reserves by oil production (and instrumented by lagged oil reserves), once again, we find the statistical association between oil and civil conflict disappears once country fixed effects are included. Second, because political violence can take many forms, we extend the existing literature by considering other measures of political violence. Using a similar panel specification, we also do not find that oil abundance has any effect on military coup attempts or irregular leader transitions. Interestingly, we do find a significant correlation between oil reserves and military spending among nondemocratic countries. These results suggest that the first-order effect of oil abundance on macro-political violence is perhaps the expansion of military power, rather than more violent challenges to the state.

While the fixed-effects estimation is useful in removing the influence of long-run determinants of both oil abundance and civil war, it does not necessarily estimate the causal effect of oil on civil war because oil exploration may be endogenous (David and Wright, 1997). ${ }^{2}$ Our second strategy is a quasi-experimental approach that exploits randomness in the success or failure of oil explorations, conditional on a serious attempt being made to find oil. It is well known that oil exploration is a hit-or-miss business. It is rare for the first exploratory borehole, also known as wildcat, in a new area to succeed. Even with the most advanced technology, the success rate of finding commercial oil is still less than half. ${ }^{3}$ It is therefore plausible to treat oil discoveries as positive oil wealth shocks. The identification assumption for our discovery specification is that the discovery of oil can be treated as plausibly exogenous, conditional on exploration drilling. However, oil explorations are motivated by the expectation to find oil, and the profitability of successful exploration may be correlated with political stability (Bohn and Deacon, 2000). We re-estimate the impact of oil discovery on conflict with the entire sample of country-years for which exploration data are available using propensity score matching to control for selection into exploration. Using the matching method, we predict when oil exploration will occur, and then we stratify the sample according to the likelihood of exploration. Making

\footnotetext{
${ }^{2}$ Moreover, the fixed-effects estimation may exacerbate an attenuation bias caused by measurement error by removing a significant portion of the variation in the right hand side variables.

${ }^{3}$ The odds were even smaller for the most part of the oil history. According to the U.S. Energy Information Administration, $46 \%$ of the exploratory wells found commercial quantities of oil or natural gas in the U.S. in 2003, and the figure was only $22 \%$ in 1973.
} 
comparisons between years with exploration efforts and years without within comparable contexts, once again, this approach shows that oil discoveries are not causally linked to any of our measures of violent challenges to the state; rather, oil discoveries increase military spending in the subsample of nondemocratic countries. ${ }^{4}$

Many studies of the natural resource-civil war relationship, based on cross-country comparisons, argue that there is a robust statistical association between oil abundance and civil war onset. Collier and Hoeffler $(1998,2004)$ find that natural-resource dependence has a positive effect on the onset and duration of civil war at low levels of natural resource dependence and a negative effect at high levels of natural resource dependence. Oil exports, in particular, have a distinct effect on the risk of civil war. These findings, however, are challenged by Fearon and Laitin (2003) and Fearon (2005), who argue that these results reflect omitted variables (including weakness of the economy) rather than a causal relationship. ${ }^{5}$ Brunnschweiler and Bultey (2009) show that conflict increases dependence on resource extraction. ${ }^{6}$ Humphreys (2005) and Ross (2006), on the other hand, argue that using some improved measures of oil and diamond deposits, resource abundance has a robust positive effect on the onset of civil war. Because of data availability, all these studies examine the post-1960 period, and none of them attempt to control for unobserved country-specific heterogeneity using fixed effects. The omitted-variable and endogeneity biases, as well as measurement problems, are perhaps responsible for some of these contradictory findings based on cross-country evidence.

Miguel, Satyanath, and Sergenti (2004) are the first to adopt an instrumental-variable approach in studying the determinants of civil war using variation in incomes resulting from rainfall. Contrary to the resource-curse argument, they find that temporary negative economic shocks trigger civil conflict. ${ }^{7}$ However, using within-country variation, Besley and Persson

\footnotetext{
${ }^{4}$ These results hold in general even without controlling for fixed effects, which alleviates the concern that our results are driven by a potential exacerbation of measurement error attenuation bias in the framework of a fixedeffects estimation.

${ }^{5}$ In their view, the major determinants of civil war are the conditions that favor insurgency (such as poverty and rough terrain), but not ethnic or religious characteristics. However, Montalvo and Reynal-Querol (2005) show that ethnic heterogeneity, measured by ethnic polarization, is a significant explanatory variable for the incidence of civil wars. See also Field et al. (2008) for the effect of segregation on riots.

${ }^{6}$ Indeed, Brunnschweiler and Bultey's results indicate that via an income effect, aggregate resource wealth lowers the probability of major conflict. In an earlier paper, however, Smith (2004) finds that oil dependence has a negative effect on the incidence of civil war. Hegre and Sambanis (2006) and Sambanis (2004) argue that the effect of natural resource and oil dependence on civil war onset is in general not robust.

${ }^{7}$ See also Oster (2004) and Miguel (2005) for the effect of negative economic shocks on violence.
} 
(2008) report that higher prices of exported commodities raise the probability of observing conflict, and higher prices of imported commodities raise the probability of civil war. In the case of oil, Tsui (forthcoming) demonstrates that oil discovery provides a useful source of variation to estimate the long-term impact of oil abundance on democracy. We extend the empirical framework developed by Tsui and assemble a new panel dataset on oil explorations, discoveries, and reserves in this paper to estimate the short-to-medium-term impact of oil abundance on civil war as well as coup attempts, irregular leader transitions, and military spending. ${ }^{8}$

More recently, another body in the literature has emerged that provides micro-level evidence on the resource-conflict relationship by exploiting regional variation in resource abundance. Angrist and Kugler (2008) examine the impact of upsurge in coca prices on violent death rates in Colombia, and they report increased violent death rates in growing areas after the increase in coca cultivation. Dube and Vargas (2009) show that again in Columbia a fall in coffee prices increases violence in regions growing more coffee and a rise in oil prices increases violence in the oil region, where violence is measured by the number of attacks, clashes, and war-related casualties. These novel studies provide solid micro-level evidence of the impact of short-run fluctuation in resource value on conflict intensity in Columbia. More work is needed to be done before one can conclude if these results can be generalized in other countries. Using casualties or the number of attacks as the main dependent variables, this micro-empirical approach attempts to explain the intensity of conflict (an intensive margin), rather than the onset of conflict (an extensive margin) as in the literature based on cross-country comparison. All these outcome variables are important to be examined. However, since the determinants of regional violent crime and national insurgency need not be identical, we may not be able to obtain the impact of oil on civil war in a country by adding up the oil effects on violence from individual regions. ${ }^{9}$ Since we are interested in large-scale civil conflicts triggered by the prospect of capturing oil wealth in office and government's macro responses to insurgent groups, we view our study complementary to these micro-level analyses.

\footnotetext{
${ }^{8}$ In section 5 , we also provide additional evidence on a long-run impact of oil abundance on political violence.

${ }^{9}$ The micro-macro paradox — where micro and macro estimates largely disagree — appears in various literature. Acemoglu (2009) argue that counterfactual analysis based on microdata that ignores general equilibrium and political economy issues may lead to misleading conclusions. In the case of civil war, resource boom or bust in one region but not others may shift the battlefield from the later to the former, without any significant effect at the country level. Or the opposite can be true if there is a multiplier effect for social unrest.
} 
The paper proceeds as follows. Section 2 describes the dataset and explains how it can help address the endogeneity and measurement problems. Section 3 presents the results based on the standard panel method using oil reserves as the main regressor. Section 4 discusses our main empirical strategy which exploits inherent randomness in the success or failure of oil exploration and presents further evidence based on this strategy. Section 5 provides sensitivity checks. Section 6 discusses interpretations of our findings and concludes.

\section{Data Sources and the Endogeneity and Measurement Problems}

Our fixed-effects estimation strategy exploits within-country variation in oil reserves so that we can control for possible country-specific omitted factors that do not change over time. The validity of this strategy hinges on both the quality and the quantity of the oil-reserves data, because fixed-effects estimations may exacerbate measurement error by removing a significant portion of the variation in the right-hand-side variables.

\subsection{Data Sources}

Oil Exploration, Discoveries, and Reserves Data. Our oil exploration and discovery data are obtained from Dr. Colin Campbell at the Association for the Study of Peak Oil (ASPO), a nonprofit organization that is devoted to gathering industrial data to study the dates and impact of the peak and decline of world oil. A major advantage of the ASPO dataset over public data (e.g. BP and OGJ, see below) is that it provides detailed information on both oil discoveries and production, and hence oil reserves at any given year can be computed based on past and new discoveries and depletion. Such backdating reserves revisions remove any suspicious drastic changes in reserves without any significant discovery being identified and any implausibly unchanged reserves. The spurious nature of the reserves reported by the major OPEC countries has long been recognized, especially since the implementation of the production quota system in 1982. According to the BP Statistical Review of World Energy, a widely used source of public data, Kuwait reported a $50 \%$ increase to its reserves in $1984 .{ }^{10}$ A year later, Venezuela doubled its reported reserves ${ }^{11}$ and United Arab Emirates even tripled its. ${ }^{12}$ Similar pattern is observed in

\footnotetext{
${ }^{10}$ Kuwait's reported oil reserves increased from 67 billion barrels in 1983 to 93 billions barrel in 1984.

${ }^{11}$ Venezuela's reported oil reserves increased from 28 billion barrels in 1984 to 54 billions barrel in 1985.

${ }^{12}$ UAE's reported oil reserves increased from 33 billion barrels in 1985 to 97 billions barrel in 1986.
} 
the Iran, ${ }^{13}$ Iraq, ${ }^{14}$ and Saudi Arabia's ${ }^{15}$ data. On the other hand, these OPEC countries had reported almost identical figures for many years since these dramatic revisions. Because the OPEC quota is set based on member country's production capacity, the reliability of these selfreported reserves data is highly questionable (Laherrere, 2001).

The ASPO dataset contains a panel of oil discovery and oil production for the top 62 oil countries over the period 1930-2003. Information on cumulative discovery and production before 1930 is also available. These enable us to construct a long panel of oil reserves. In particular, oil reserves for each country at any particular year are calculated by subtracting cumulative production from cumulative discovery. In addition, the ASPO dataset also provides information on oil exploration activities, namely, the number of wildcats drilled. According to our data, global oil discovery peaked in the early 1960s, with many oil-rich Middle East and African countries having their peak discovery years during the 1940s and 1960s, respectively. This time pattern of oil discoveries casts considerable doubt on the reliability of the 300 billion barrels of oil reserves that were added during the late 1980s according to the public data. Moreover, because most of the public data only cover the period since 1970, previous studies based on these data miss a great deal of within-country variation in oil abundance. In addition to removing suspicious drastic changes in reserves and implausibly unchanged reserves, another advantage of our dataset is that it allows us to follow many countries from the time before their first oil discovery, and hence it provides significant within-country variation in oil abundance which is crucial for our fixed-effects estimation.

The ASPO dataset covers most oil countries. In our baseline sample, we also include countries which have zero oil endowment according to two public databases: BP Statistical Review of World Energy (BP), Oil and Gas Journal (OGJ), and CIA factbook. In some specifications, our sample also includes other small oil-producing countries identified by the public databases. Since these countries have either zero or very small oil reserves, and more importantly because they have less incentive to misreport, measurement error is bound to be negligible. Our results are very similar across these different samples.

\footnotetext{
${ }^{13}$ Iran's reported oil reserves increased from 59 billion barrels in 1985 to 93 billions barrel in 1986.

${ }^{14}$ Iraq's reported oil reserves increased from 72 billion barrels in 1986 to 100 billions barrel in 1987.

${ }^{15}$ Saudi Arabia's reported oil reserves increased from 170 billion barrels in 1987 to 255 billions barrel in 1988.
} 
Civil War, Coup Attempts, Irregular Leader Transitions, and Military Spending Data. Civil conflict data are taken from Gleditsch's revision of the Correlates of War dataset (GleditschCOW, version 1.52) and the UCDP/PRIO Armed Conflict Dataset (UCDP/PRIO, version 42007). The Gleditsch-COW dataset contains data on armed conflicts with over 1,000 battle deaths from 1816 to 2005 . The UCDP/PRIO dataset contains data on both major armed conflicts (over 1,000 battle deaths per year) and minor ones (25-999 battle deaths per year) over the period 1946-2006. All country-year observations with a civil war incidence with at least 1,000 battle deaths per year (or 25 battle deaths in some specifications) are coded as ones, and other observations are coded as zeros. Following Miguel, Satyanath, and Sergenti (2004) and Ross (2006), we study the impact of oil abundance on major conflicts and all conflicts collectively. Also, following the literature, we examine both conflict onset and conflict incidence, ${ }^{16}$ where in the case of onset we restrict our attention to country-year observations in which there was no civil conflict during the previous year.

The Center for Systemic Peace (CSP) provides data on military coup attempts. This dataset contains information on all coups d'état occurring each year in countries with populations greater than 500,000 during the period 1960-2006. The total number of coups, including both successful and unsuccessful ones, occurring for any country at each year is used as a dependent variable. Another measure of violent challenges to the state is derived from the Archigos dataset of political leaders over the period 1875-2004. Following Jones and Olken (2009), we compute the percentage of leader transitions over the following twenty years that are "irregular" — i.e. transitions that are unlawful and not according to the country's prevailing rules, provisions, conventions and norms. Finally, the Stockholm International Peace Research Institute (SIPRI) provides data on the defense burden (i.e. military spending as a fraction of GDP) for the period since 1988.

Other Variables. Other control variables include per capita income, economic growth, population, population density, democracy, mountainous, ethnic, religious, and language fractionalization and polarization, and a dummy for whether the country has a British legal origin. Income and population data are taken from Maddison's Statistics on World Population, GDP and Per Capita GDP, 1-2006 AD, because it contains historical data that are needed for our

\footnotetext{
${ }^{16}$ More precisely, our discovery specification focuses on changes in conflict incidence.
} 
analysis. The CIA World Factbook provides data on country area. Democracy data are taken from the Polity IV dataset. The mountain data are obtained from Gerrard (2000). Data on fractionalization and polarization are taken from Alesina et al. (2003) and Montalvo and ReynalQuerol (2005), respectively. Finally, legal original data are available from the Easterly's Global Development Network Growth Database.

\subsection{Descriptive Statistics}

Descriptive statistics are summarized in Table 1. The first column reports the sample mean and standard deviation for the whole sample. In the next three columns, countries are classified into three groups according to their abundance of oil, as measured by oil reserves per capita. The last column reports the F-statistics under the hypothesis that the variables of the three country groups have the same mean. Panel A of table 1 presents the descriptive statistics of our main regressors oil reserves and oil discoveries. Panel B shows those of the various measures of political violence. Other country characteristics and control variables are reported in panel C.

Several remarks are in order. First, according to panel A, the distribution of oil abundance is right-skewed. ${ }^{17}$ Moreover, countries with more oil reserves tend to discover larger oil fields. Second, although it is commonly said that political violence is extremely rare, panel B shows that civil war, coup attempts, and irregular leader transitions are not that uncommon. ${ }^{18}$ Third, although both civil war incidence and onset appear to be positively correlated with oil abundance, the differences in the likelihood of civil war across the three groups are small and the raw correlations are not statistically significant because within-group variations are large. Fourth, oil-rich countries are not more likely to have military coups or irregular leadership transitions. Rather, oil-rich countries spend significantly more on their militaries. For example, the average $\log$ of defense burden among the most oil-rich countries is three times larger than that among those countries with no oil. These raw correlations anticipate our main result that oil abundance

\footnotetext{
${ }^{17}$ For countries with no oil reserves, we impute the zeros by dividing the smallest observed value from the data by 1000. Our results are robust to other similar imputation schemes, such as dividing the smallest values by an even larger number, adding all oil reserves per capita by a positive constant, or simply using level of oil reserves per capita. Similar imputation applies to the oil discoveries per capita variable. Moreover, to increase the readability of the regression results, we divide the log oil reserves per capita and the log oil discovery per capita variables by 100 throughout the paper.

${ }^{18}$ The frequency of either a civil war or coup attempt is almost ten percent in our sample, and the average percentage of irregular leader transitions is even higher. These statistics suggest that violent challenges to the state are not an insignificant part of political life.
} 
increases the defense burden instead of causing more violent challenges to the state. Finally, there are no systematic differences in most observable country characteristics except for GDP per capita: oil-rich countries tend to be wealthier. Economic growth, population, population density, and ethnic fractionalization also appear to be somewhat different across groups, but the relationships are not monotonic in oil abundance. Also, countries with more oil reserves tend to drill more wildcats. To the extent that there are unobserved characteristics across country that are correlated with the observed heterogeneity, introducing country fixed effects can help mitigate the omitted variable bias.

\section{Fixed-effects Estimation Using Oil Reserves as a Measure of Oil Abundance}

The existing literature, based on pooled OLS estimation and panel data on oil exports or production as a proxy for oil abundance, does not adequately address the omitted-variable bias and the problem of measurement error. Before we present our main results in Section 4, which are based on the inherent randomness in the success or failure of oil exploration, in this section we first re-examine the oil-fuels-war hypothesis using country fixed effects to control for country-specific factors affecting both oil abundance and civil war. The idea of fixed effects is to investigate the "within-country variation," that is to ask whether a country is more or less likely to suffer from civil war as it becomes more or less rich in oil (i.e. changes in oil reserves caused by oil discoveries or depletion). ${ }^{19}$ While the fixed effects estimation does not necessarily identify the causal effect of oil on civil war for reasons discussed in detail below, the estimation provides a useful benchmark that permits a comparison with previous findings.

\subsection{Estimation Framework Using Oil Reserves}

Consider the following simple econometric model:

$$
\operatorname{CONFLICT}_{\mathrm{it}}=\beta_{1} \operatorname{RESERVES}_{\mathrm{it}}+\mathrm{X}_{1, \mathrm{it}}{ }^{\prime} \gamma_{1}+\delta_{1, \mathrm{i}}+\mathrm{u}_{1, \mathrm{it}}
$$

where CONFLICT $\mathrm{C}_{\mathrm{it}}$, following the existing literature, is the civil war onset of country $\mathrm{i}$ in period $\mathrm{t}$ (the " 1 " subscript denotes the equation number here). The main variable of interest is

\footnotetext{
${ }^{19}$ This approach is also more relevant to the current debate on how more transparent resource wealth management and better institution may help individual oil-rich countries escape the resource-curse problem (Humphreys et al., 2007). A similar argument was put forth by Rajan and Subramanian (2008) in the case of foreign aid and economic growth, where they document that the inclusion of country fixed effects is not typical in the aid-growth literature, despite the well-known problems from the cross-sectional regressions.
} 
RESERVES $S_{i t}$, the log oil reserves (measured in billions of barrels) per capita. ${ }^{20}$ The parameter $\beta_{1}$ therefore measures the causal effect of oil abundance per capita on civil war onset. All other potential covariates are included in the vector $X_{1, i t}$. The vector of time-varying country characteristics $X_{1, \mathrm{it}}$ includes per-capita GDP, GDP growth, population, population density, and democracy. ${ }^{21}$ In addition, $\delta_{1, \mathrm{i}}$ denotes country fixed effects. $\mathrm{u}_{1, \mathrm{it}}$ is an error term, capturing all other omitted factors, with $\mathrm{E}\left(\mathrm{u}_{1, \mathrm{it}}\right)=0$ for all $\mathrm{i}$ and $\mathrm{t}$.

The standard regression in the literature (e.g., Ross, 2006) is a pooled OLS, which is identical to (1) except (a) the use of some flow measure (such as oil production) as a proxy for oil abundance and (b) the omission of the fixed effects, $\delta_{1, \mathrm{i}}{ }^{\prime}{ }^{22}$ In our framework, oil abundance is measured directly by oil reserves, and the country dummies capture any time-invariant country characteristics that affect civil war onset. Theoretically speaking, the "Hotelling Valuation Principle" says that the value of oil reserves is proportional to the size of the reserves (not production) (Miller and Upton, 1985, and Davis and Cairns 1999). In practice, reserves and production are not proportional to each other because there are typically a few years of development lag between oil discovery and first production, and the production profile of each oilfield follows an inverted U-shaped pattern over time because of geological constraints. Production also understates the oil wealth of swing producers that produce below their full capacity. As is well known, when the main variable of interest is subject to measurement error, the estimate of $\beta_{1}$ is biased and inconsistent. Furthermore, because the flow measures of oil abundance are likely to be directly affected by civil war (i.e. Cov (PRODUCTION $\left.\mathrm{i}_{\mathrm{i}}, \mathrm{u}_{1, \mathrm{it}}\right) \neq 0$ ), the direction of the bias is ambiguous. In addition, when the true model is given by (1) and the $\delta_{1,1}$ 's are correlated with RESERVES ${ }_{\text {it }}$ or $\mathrm{X}_{1, \mathrm{it}}$, pooled OLS estimates are biased and inconsistent.

\footnotetext{
${ }^{20}$ We choose this measure as our main specification because it is the closest to the measure being used in the existing literature, with oil reserves replaced by oil exports or oil production. We also experiment with various ways to measure oil abundance, such as (a) log of 1-year lagged oil reserves per capita, (b) the level of oil reserves per capita, and (c) the log of oil reserves. The results are very similar and to save space they are not reported.

${ }^{21}$ In the pooled regressions, to compare our results with the previous studies, we follow the existing literature on civil war and consider country-specific but time-invarying covariates including mountainous area, ethnic fractionalization, religion fractionalization, language fractionalization, and a dummy for British legal origin. In some specifications, instead of controlling for ethnic fractionalization, we use ethnic polarization as a control.

${ }^{22}$ To highlight the importance of the potential bias due to the omission of time-invariant country-specific factors from the existing literature, we focus our presentation on the country fixed effects. Moreover, introducing too many fixed effects may reduce the useful variation in oil abundance. In any case, we experimented with different specifications, including time fixed effects and country-specific time trends, and the results are robust across specifications (see table 10 below).
} 


\subsection{Initial Evidence from the Fixed-Effects Estimation}

We begin by estimating (1) using data from the Gleditsch-COW and the UCDP/PRIO datasets, with the sample periods 1930-2003 and 1946-2003, respectively. ${ }^{23}$ To compare our results with the existing findings, we follow the existing literature and study the effect on both the onset of intense civil war (i.e. major armed conflict with greater than 1,000 battle deaths) and all conflict (i.e., all armed conflict with greater than 25 battle deaths annually).

The first two columns of table 2 report the probit and the standard pooled OLS regressions commonly found in the literature using the Gleditsch-COW data. ${ }^{24}$ Consistent with previous findings, we find that having more oil reserves is statistically associated with a higher likelihood of the onset of civil war in this simple pooled cross-country time-series setting. Though statistically significant, the effect of oil reserves is quantitatively small. In particular, a point estimate of 0.076 from the pooled OLS regression implies that a 10 percent increase in oil reserves per capita corresponds to an increase in the probability of civil war onset by less than 0.8 percentage point. Other coefficients also seem to be plausibly estimated and are consistent with previous findings. For example, GDP per capita and economic growth are negatively correlated with civil war onset, whereas mountainous terrain appears to be positively correlated with war. ${ }^{25}$ Since the results using probit and linear specifications are very similar, from this point forward we restrict our attention to the linear specifications.

Column 3, however, shows that the relationship between oil reserves and civil war onset disappears once country fixed effects are included. The coefficient of 0.020 with a standard error 0.054 is highly insignificant. Not only do the estimates become highly insignificant once the country fixed effects are included, but the magnitude of coefficient also becomes 3 times smaller.

\footnotetext{
${ }^{23}$ We have an unbalanced panel because we do not have all historical data going back to 1930 for all countries. Indeed, some countries did not become independent until the 1960s.

${ }^{24}$ Errors are allowed to be heteroskedastic and correlated within country over time. Thus, robust standard errors clustered at country level are reported throughout the paper.

${ }^{25}$ Also consistent with the existing literature, in the Gleditsch-COW sample, none of the coefficients on fractionalization is significant. When we replace these measures of fractionalization by polarization (Montalvo and Reynal-Querol, 2005), the sample size becomes smaller but the oil coefficient is robust to these specifications. In particular, the OLS estimate becomes 0.064 (standard error $=0.031$, and hence significant at the $5 \%$ level) in the Gleditsch-COW sample and 0.129 (standard error $=0.047$, and hence significant at the $1 \%$ level) in the UCDP/PRIO sample. Neither the ethnic polarization coefficient nor the religious polarization coefficient is significant. However, using a larger sample which includes additional oil-producing countries from the public databases, the ethnic polarization coefficient is marginally significant in the UCDP/PRIO sample (point estimate $=0.019$, standard error $=$ 0.011 , and hence significant at the $10 \%$ level), although it is not significant in the Gleditsch-COW sample.
} 
The one standard error bands of the fixed-effects estimate indeed exclude the pooled OLS estimate. This pattern is similar when using the UCDP/PRIO data (columns 4 and 5). We obtain similar results if we use a larger sample which includes additional oil-producing countries from the public databases. ${ }^{26}$ One may suspect that oil abundance may have different impacts on political violence, depending on the political institution. We consider in columns 6 and 7 the subsamples of democratic and nondemocratic countries separately. ${ }^{27}$ Once again, oil reserves are uncorrelated with the onset of civil war in both subsamples.

Although oil wealth is more accurately measured by reserves than by production, the appropriable oil wealth depends also on the expected tenure in office if a leader in an oil-rich country can capture the oil revenue only while he is in power. In the extreme case when leaders can stay in power for only one year and cannot capitalize any future oil revenue, leaders will act as if they are myopic and care about only current production. In reality, leaders' discount rate is likely to be less than infinity but also above the market interest rate, and hence the relevant measure of oil abundance should fall somewhat between reserves and current production. Estimating the effect of oil production is more difficult, because oil production is likely to be affected by war. Assuming leaders are myopic, however, we can use lagged oil reserves as an instrument for current oil production, because from discovery to first production there is a development lag ranging from about two years for onshore major fields to around 10 years for offshore oilfields (Laherrere, 1998). Table 3 presents the result using a 5-year lag of oil reserves to instrument the log of oil production per capita, which is treated as an endogenous regressor. The estimates of the oil coefficient are positive and statistically significant in the pooled OLS regression (columns 1 and 4). For example, using the Gleditsch-COW data, the pooled OLS estimate is 0.058 (standard error $=0.030$, and hence statistically significant at the $10 \%$ level). However, the magnitude of the estimates declines and becomes insignificant once country fixed effects are included in both the OLS and the 2SLS specifications. Indeed, with country fixed effects, the OLS estimates become negative, and the one standard error bands of the fixed-effects OLS estimates comfortably exclude the pooled OLS estimates (columns 2 and 5). Since neither

\footnotetext{
${ }^{26}$ For instance, using the Gleditsch-COW data, the oil coefficient reduces from 0.065 (standard error $=0.030$ ) to 0.019 (standard error $=0.052$ ). Similarly, using the UCDP/PRIO data, the oil coefficient reduces from 0.105 (standard error $=0.043$ ) to 0.049 (standard error $=0.070$ ). Furthermore, using only the public data, we also find there is no significant correlation between oil reserves and civil war onset once we control for country fixed effects.

27 A country is defined as democratic if its democracy score is above 0.5 in a $0-1$ scale. We experiment with different cutoffs and obtain qualitatively similar results (results are available upon request).
} 
oil reserves nor production are correlated with civil war onset once we control for country fixed effects, oil abundance does not appear to be a major determinant of civil conflict onset.

\subsection{Coup Attempts, Irregular Leader Transitions, and Military Spending}

The cautious reader may wonder whether the lack of a correlation between oil abundance and civil conflict onset from the fixed-effects estimation is an artifact of imprecise measures of both civil conflict and oil abundance. As is well known, to the extent that oil reserves are measured with error, fixed-effects estimations tend to exacerbate the attenuation bias. This does not seem to be the case, as our measure of oil abundance is computed based on industrial data on oil discoveries and extractions, and the relationship between oil and civil war is estimated relatively precisely. Second, the arbitrary 1,000- or 25-death threshold the databases use to identify a civil war has long been criticized. ${ }^{28}$ In this section, we provide further evidence by considering other measures of political violence that have not been studied in the resource curse literature.

We consider three additional measures of macro-political violence: military coup attempts, irregular leader transitions, and military spending. First, the coup variable captures all successful, attempted, plotted, and alleged coup events, without using any arbitrary threshold based on a fatality rate. It also complements the civil war databases because victories by oppositional forces in civil wars are not considered to be coups. We follow Jones and Olken (2009) to construct our second dependent variable, which measures the fraction of irregular leader transitions over the following 20 years. ${ }^{29}$ This variable includes all actual violent leadership turnovers that could have been driven by civil war or coup, and it enables us to capture the medium-run impact of oil abundance on political violence. On the other end of the spectrum, conflict may not lead to actual leadership turnover or even attempt to challenge the state at all, because actual fighting can be deterred by repression. We use defense burden as an

\footnotetext{
${ }^{28}$ For one thing, there is a possibility of a biased sample in the case of a lower-level conflict, because it is relatively difficult to assemble the population of all such events given differences in media coverage, which can lead to underreporting of conflicts in areas where foreign reporters are thin on the ground (Gleditsch, 2004). A high battledeath threshold, however, will exclude many forms of conflicts that may not involve any casualties or minor armed disputes with few fatalities. The lack of a correlation between oil abundance and civil war, therefore, does not necessarily refute the more general hypothesis that oil abundance causes violent challenges to the state because political violence can take various forms.

${ }^{29}$ In the irregular leader transitions regressions, some countries in our sample have no transition at all over the following twenty years. We distinguish these situations from observations with transitions but no irregular ones, by adding a dummy for no transitions
} 
indicator of this political barrier to entry, because this is one important policy that limits political competition (Mulligan, Gill, and Sala-i-Martin, 2004; Tullock, 1987). ${ }^{30}$

The results are summarized in Table 4. First, for the coups regressions, the oil coefficient is positive and marginally significant only in the pooled OLS specification using the subsample of nondemocratic countries. ${ }^{31}$ Once country fixed effects are included, none of estimated coefficients are significant. In the case of irregular leader transitions, the estimates are positive and statistically significant in the sample of all countries, as well as in the subsample of nondemocratic countries. However, once again the result is not robust to the inclusion of fixed effects. Notice also that in both sets of regressions, once country fixed effects are included, the magnitude of the coefficients decline sharply and in some cases they become even negative.

Interestingly, the case of defense burden is different. In the sample of all countries (panel A), the estimated coefficient is 2.930 (with a standard error of 1.213 , which is significant at the $5 \%$ level) in the pooled OLS regression. Unlike other measures of political violence, in the case of defense burden, the size of the point estimate from the fixed-effects estimation remains essentially unchanged, although it becomes insignificant (panel A, column 6) ${ }^{32}$ When we divide the sample into democratic and nondemocratic countries (panels B and C), in our preferred fixed-effects specification, more oil reserves are found to increase the defense burden among nondemocratic countries, although there is no effect among democratic countries. In particular, our estimation implies that the elasticity of the defense burden with respect to oil abundance is 0.39 among nondemocratic countries. These results are in general robust to using a larger sample which includes additional oil-producing countries from the public databases. Since once we control for country fixed effects, we do not find any significant correlations between oil abundance and several measures of violent challenges to the state, but we do find a significant correlation between oil abundance and defense burden among nondemocratic countries, measurement error alone is unlikely to drive all these results.

\section{Quasi-Experimental Approach Using the Success and Failure of Oil Explorations}

\footnotetext{
${ }^{30}$ Note that by using defense burden as an indicator of entry barriers, we do not mean that military spending serves only the purpose of blocking political entry from local challengers; it will also deter foreign invasion.

${ }^{31}$ Indeed, if we use a larger sample which includes additional oil-producing countries from the public databases, even the pooled OLS estimates are insignificant.

${ }^{32}$ Note that the coefficient remains significant if we use a larger sample which includes additional oil-producing countries from the public databases.
} 
The results from the previous section shed considerable doubt on the claim that oil has a robust causal effect on civil wars (Ross, 2004 and 2006). Nonetheless, there should be no presumption that fixed-effects regressions necessarily estimate the causal effect of oil abundance on civil war, because the estimation of causal effects requires exogenous sources of variation. Although compared with oil exports or production, oil reserves is a better indicator of oil wealth and is arguably less likely to be endogenous to civil war, there is still a concern that oil reserves may be affected by political stability through extraction and exploration decisions.

To establish a causal relationship, in this section, we exploit randomness in the success and failure of oil discoveries, conditional on the intensity of exploration attempts. Oil exploration is a risky business and to a large extent the outcome of wildcat drilling is a matter of chance. Our approach is therefore similar to Jones and Olken's (2009) idea of exploiting randomness in the success or failure in assassination attempts to identify the effect of the outcome of assassination on institutional change and war, and using matching method to control for selection on assassination attempts. To implement this approach, we assemble data on international exploratory drilling, oilfield discoveries, and other determinants of wildcat drilling since $1930 .^{33}$

\subsection{Is Success in Oil Exploration Random?}

We begin by asking the following question: Is success in oil exploration random? While this assumption cannot be tested directly, we can provide suggestive evidence by investigating whether any observed variables predict successful oil exploration.

In Table 5, we present the mean values of a number of variables in the year prior to wildcat drilling, as well as the result from two-sided t-tests for the equality of these means. The table shows that the subsamples of successful and failed oil exploration are balanced across a wide variety of variables: log GDP per capita, economic growth rate, log population density, religious and language fractionalization, legal origin, and the number of wildcats drilled. Differences in $\log$ mountainous, ethnic fractionalization, and democracy are only marginally significant at the $10 \%$ level. However, it appears that success is significantly correlated with $\log$ oil reserves per capita and log population. In particular, previous exploration success predicts the

\footnotetext{
${ }^{33}$ In this discovery specification, therefore, our sample is taken exclusively from the ASPO data, where information on wildcat drilling is available.
} 
success of future exploration. Oil explorations also seem to be more successful in more populated countries. Given that we have examined 12 variables, it should not be too surprising that a few of them be statistically significant. If oil reserves trigger conflict and populated countries have more civil war (Raleigh and Hegre, 2009), to the extent that there are unobserved regime characteristics which predict exploration success and are positively correlated with both lagged oil reserves and population, our estimate provides an upper bound of the effect of oil abundance on political violence.

\subsection{Predicting Oil Exploration}

Even when the outcome of oil exploration is exogenous, attempts to find oil may be correlated with conflict. To check the robustness of our results based on luck in exploration success, we use propensity score matching method to control for selection in attempts to find oil. The advantage of this approach is that it provides a flexible way to dealing with selection on observables.

The geology literature provides some indication about the best predictors of wildcat drilling: measures of discovery expectations and profitability (Drew, 1975). In this paper, we use lagged oil reserves per capita, lagged oil price, lagged democracy, and lagged war incidence to

predict the likelihood of wildcat drilling. With this set of determinants of wildcat drilling, ${ }^{34}$ we construct propensity score and stratify the sample according to the likelihood to drill so that we are making comparisons between years with exploration attempts and years without within comparable contexts.

Table 6 shows the results from logit specifications that estimate some determinants of wildcat drillings, and hence predict the likelihood of oil exploration. According to columns (1) and (2), the probability of exploration attempts is higher in country-year observations when lagged oil reserves are large and oil price is high. Because oil resources are geographically concentrated, the size of existing reserves is a good indicator of the prospect of discovery. Higher oil price also increases the profitability of successful exploration. In addition to these economic factors, wildcat drillings are also predicted by political factors. Oil exploration is more common in democracies and during peace time.

\subsection{Main Results: The Effects of Oil Discoveries}

\footnotetext{
${ }^{34}$ When necessary, we also add higher order terms and interactions to construct propensity score.
} 
Based on the predicted probability from the previous section, we form blocks, denoted by $b$, for different levels of propensity score, where the covariates are balanced between countries with and without wildcat drillings within each block. Following Jones and Olken's (2009), we estimate regressions of the form

$$
\mathrm{y}_{\mathrm{it}}=\alpha_{2 \mathrm{~b}}+\beta_{2} \text { DISCOVERY }_{\mathrm{it}}+\theta_{2} \text { WILDCAT }_{\mathrm{it}}+\mathrm{X}_{2, \mathrm{it}}{ }^{\prime} \gamma_{2}+\delta_{2, \mathrm{i}}+\mathrm{u}_{2, \mathrm{it}},
$$

where $y_{i t}$ is an outcome of interest for country $i$ at year $t$ (i.e., change in civil war status, coup attempt, or defense burden before and after the exploration, and fraction of leader transitions over the following 20 years that are irregular). We also experiment with other measures of before and after using longer differences (see footnotes 37 and 38). $\alpha_{2 b}$ indicates fixed effects for each propensity score block. ${ }^{35}$ DISCOVERY ${ }_{\text {it }}$, measured as the $\log$ of oil discovery, ${ }^{36}$ is assumed to be uncorrelated with $\mathrm{u}_{2, \mathrm{it}}$, conditional on $\alpha_{2 \mathrm{~b}}$, WILDCAT $\mathrm{W}_{\mathrm{it}}, \mathrm{X}_{2, \mathrm{it}}$, and $\delta_{2, \mathrm{i}}$. The controls are identical to those in regression (1) except that (a) lagged oil reserves is also included, and (b) all other covariates are measured at $\mathrm{t}-1$.

Table 7 examines the effect of oil exploration outcomes on various measures of violent challenges to the state. Panels A and B present results on civil war using the two different datasets, whereas panels $\mathrm{C}$ and $\mathrm{D}$ show the effect on coup attempts and irregular leader transitions, respectively. For each panel, the first two columns report the pooled and fixed-effects OLS results using the sample of observations in which there is at least one wildcat drilled, and the next two columns report the estimates using the matched sample, which included as well country-year observations in which there is no wildcat drilled. In particular, the last column reports the results with both fixed effects and propensity score stratification.

The main result from table 7 is easy to summarize: oil discoveries have no significant impact on any measure of violent challenges to the state, a finding consistent with our previous

\footnotetext{
${ }^{35}$ Following some of the existing literature, the common support is determined by the observations whose propensity score belongs to the intersection of the supports of the propensity score of treated and controls. The common support is partitioned into intervals/strata such that the mean values of the estimated propensity scores are not statistically different in each interval. Upon completing the matching, balancing tests are performed. When covariates were still unbalanced, the specification of the propensity score was enhanced with higher order terms and interactions (Dehejia and Wahba, 1999). As a result of this algorithm we formed 9 strata for the sample used in the war Gleditsch-COW specification, 11 strata for the war UCDP/PRIO specification, 9 strata for the coup attempts specification, 7 for the irregular transitions specification, and 5 for the defense burden specification.

${ }^{36}$ Again, for observations with no oil discovery, we impute the zeros by dividing the smallest observed value from the data by 1000 and then take log.
} 
results from the oil reserves-fixed effects estimation. The result holds in both the subsample with positive wildcat and the matched sample. First, we note that except in the case of all civil conflict (panel B), none of any of our measures of political violence is related to the success or failure of oil exploration even without controlling for country fixed effects (column 1). Even in the case of all conflict, the pooled OLS estimate is only marginally significant at the $10 \%$ level, and the effect disappears once fixed effects are included (panel B, columns (1) and (2)). In the case of intense civil war, the pooled OLS and the fixed-effects estimates are essentially identical (panel A, columns (1) and (2)). A similar pattern is observed in other regressions. This is important because it reassures us that our results are not driven by the potential measurement error problem from the fixed-effects estimation. ${ }^{37}$

Second, the estimates from using the sample with positive wildcats and the matched sample are also similar. For instance, for the all civil conflict regressions, the size of the oil coefficient changes slightly from 0.141 to 0.133 when we extend the sample to include countryyears in which there is no oil exploration. The coefficient declines further to 0.075 when we control for the likelihood of drilling exploratory wells, although none of these estimates are significant. The finding that our matching estimates are insignificant and are similar to the pooled OLS and fixed-effects estimates suggests that our results based on randomness of the outcome of oil exploration are relatively stable across a variety of specifications.

The results for defense burden are presented in table 8, which has a format similar to that of table 7. Defense burden is treated separately, because as a political entry barrier it is conceptually different from civil war and other forms of violent challenges to the state. Moreover, our oil reserves-fixed effects estimation suggests that oil-rich nondemocractic countries have larger defense burdens. Using the sample of both democratic and nondemocratic countries, panel A in table 8 shows that oil discoveries and defense burden are positively correlated, although none of these estimates are significant. In the subsample of democratic

\footnotetext{
${ }^{37}$ When we restrict our sample to either all democratic or all nondemocratic countries only, the estimated effects are again insignificant (results are available upon request). Another robustness check is to use longer differences as a dependent variables, because the impact of oil discovery may take some time to develop. For example, when using as dependent variable the difference between three years after and the year prior to the year of exploration, the OLS fixed-effects estimate is 0.085 (standard error $=0.067$ ) in the civil war regression (using Gleditsch-COW Dataset). Using the difference between a three-year average after and a three-year average before the year of exploration, the OLS fixed-effects estimate is 0.096 (standard error $=0.068$ ). These estimates are very similar to our benchmark estimates and are all highly insignificant.
} 
countries, the matching estimate is indeed negative and marginally significant (panel $\mathrm{B}$, column (4)). However, panel $\mathrm{C}$ shows that nondemocratic countries spend significantly more on the military. The pooled OLS estimate is 0.703 (standard error $=0.373$ ), which is statistically significant at the $10 \%$ level. After adding country fixed effects the estimate becomes significant at the 5\% level (panel C, column 2). Using the matched sample, the oil coefficient remains significant at the $5 \%$ level. Our propensity score matching estimate is 0.822 (standard error $=$ 0.318 , and hence significant at the $1 \%$ level), which implies that a short-run elasticity of defense burden with respect to oil discovery per capita is almost $0.01 .^{38}$

\section{Sensitivity Analysis}

A range of sensitivity checks is performed and the results are reported in table 9. Odd-numbered columns report the estimated effect of oil reserves on various outcomes as specified (equation (1)), and even-numbered columns report the estimated effect of oil discovery (equation (2)). All regressions are run with the full set of controls and country fixed effects. Because the fixedeffects estimates (using the sample with positive wildcats) and the matching estimates are similar, to highlight the results based on randomness in exploration outcome, we report the fixedeffects estimates for the discovery specification.

First, in most countries all mineral resources belong to the government; however, ownership of mineral resources is private in the United States. Excluding the US from the sample, however, does not affect the results - none of the effects are significant, except the effect on defense burden among nondemocratic countries. Similarly, excluding the USSR, another oil-producing country and a major player during the Cold War, also does not affect our results. Because of market power, OPEC countries may behave differently compared with nonOPEC countries. Controlling for OPEC membership, our results remain unchanged. In the political science literature, poverty and rough terrain that favors insurgency are argued to be two of the most important determinants of civil war (Fearon and Laitin, 2003). Focusing on the subsample of low-income countries, the results are again similar. When we restrict our sample to

\footnotetext{
${ }^{38}$ Using the difference between three years after and the year before the year of exploration, the OLS fixed-effects estimate is 1.079 (standard error $=0.537$, and hence it is significant at the $10 \%$ level) in the defense burden regression with the sample of nondemocratic countries. Using the difference between a three-year average after and a three-year average before the year of exploration, the OLS fixed-effects estimate is 1.184 (standard error $=0.539$, and thus significant at the $5 \%$ significance level). These estimates are again similar to our benchmark estimates.
} 
countries with rough terrain, measured by a high fraction of mountainous area, the effect of oil discovery on defense among nondemocracies is even stronger, although the estimate is less precise under the reserves specification. In the next three rows, when we restrict our sample to the post-WWII period (i.e. years after 1946), restrict the sample to the country-year in which there is peace in the previous year, and include year fixed effects. Broadly speaking, our main findings are quite robust to these different specifications. Finally, we convert the size of the quantity of oil in barrels into dollar amounts by multiplying the quantity of oil by the price of crude oil, which varies over time. Using this oil-value estimate as a regressor, we again find that the only effect of oil wealth is on the defense burden among nondemocratic countries.

To conclude this section, we provide additional evidence on the robustness of the oilconflict relationship across longer time horizons. By exploiting randomness in the success of oil exploration, our analysis thus far has focused on the short-to-medium run impact of change in oil wealth because of discovery. Another plausible exogenous cross-country variation in oil wealth is caused by differences in initial oil endowment, which is determined by geology. Table 10 tests whether oil endowments are associated with high levels of political violence in the long run. The outcome variables are various measures of political violence averaged over the period since 1960. The key independent variable is ( $\log$ of) oil endowment ${ }^{39}$ normalized by the land area of the country. Because in the long run, income, population, and democracy are endogenous, following Alexeev and Conrad (2009), we run a highly parsimonious regression that includes geographic variables of mountainous terrain and dummies for geographical regions, ${ }^{40}$ as well as measures of fractionalization and a legal origin dummy. These independent variables are plausibly exogenous. The results from this long-run specification based on cross-country comparison are consistent with our previous findings: oil abundance, measured by endowment, is not correlated with any of our measures of political violence except defense burden.

\section{Interpretation of the Results and Concluding Remarks}

\footnotetext{
39 Data on oil endowment is also obtained from the ASPO dataset. The amount is estimated most recently by geologists, using statistical techniques involving size distributions and geological habitats. Knowledge about cumulative discovery and cumulative wildcats also contribute to the estimate. For details, see Tsui (forthcoming).

${ }^{40}$ The six regions, according to the UN classification, are Africa, Central and South America, North America, Asia, Europe, and Oceania.
} 
This study has used a unique dataset on worldwide oil explorations and discoveries to provide new cross-country evidence of the impact of oil abundance on civil war and other measures of violent challenges to the state. In particular, we exploit within-country variation in oil reserves and randomness in the success or failure of oil explorations to identify the causal effect of oil abundance on civil conflict, coup attempts, irregular leader transitions, and defense burden. Contrary to popular belief, we find no evidence that oil abundance is causally related any of our measures of violent challenges to the state. Rather, oil-rich nondemocratic countries are found to have a larger defense burden.

At a first glace, our new macro estimates based on cross-country comparison seem to be inconsistent with the recent micro estimates based on cross-region comparison. One interpretation is simply that our cross-country estimation is plagued by noise in the aggregate data, which makes it difficult to establish any relationships even if they exist. Alternatively, such a "micro-macro paradox" in the oil-conflict relationship may suggest that the determinants of regional violence (measured by the intensity of an ongoing conflict) and large-scale violent challenge to the states (measured by the onset of insurgency or violent regime change) are different. We believe that the lack of a correlation between oil abundance and violent challenges to the state is not likely to be driven by poor measures of oil abundance or political violence outcomes. First, our data on oil abundance are derived from a detailed panel database on oil discoveries and extractions that are compiled by geologists from the oil industry. Second, our oil panel data over more than 70 years provide significant within-country variation in oil abundance. Third, we extend previous studies by considering several new measures of violent challenges to the state. Fourth, our first estimation framework, which is based on the standard fixed-effects method, enables us to understand why our results differ from previous findings. Fifth, our second empirical strategy is a quasi-experimental one exploiting randomness in the success and failure of oil exploration, which is widely known to be a risky business. Sixth, our estimates, based on these two identification strategies, are rather precise and are robust to various alternative specifications, including different time horizons. Seventh, we do find that oil abundance significantly affects military spending among nondemocratic countries. Finally, in this concluding section, we attempt to provide an intuitive economic interpretation that is consistent with our empirical findings. 
The contest model, the workhorse of the traditional formal conflict literature, predicts that disputes are more likely to result in civil war when the appropriable rents are large, although this literature does not directly address the resource-curse problem (e.g., Hirshleifer, 1988; Gershenson and Grossman, 2000; Grossman, 2003). ${ }^{41}$ More recently, however, Fearon (2007) and Tsui (2009) argue that under certain circumstances violent challenges to the state are independent of the size of the appropriable rent, because more appropriable rent induces incumbent political leaders to increase their effort to defend the rent. ${ }^{42}$ In particular, Tsui (2009) shows that nondemocratic countries with lower deadweight costs of rent appropriation and marginal enforcement costs of entry deterrence are more responsive to natural resource abundance in expanding military capacity to block political competition. As a result, resource wealth will not have a significant impact on the incidence of violent challenges to the state. To successfully deter political challengers, oil-rich dictators are predicted to run more repressive regimes, and hence these oil-rich regimes will remain nondemocratic. Tsui (forthcoming) provides empirical evidence that oil abundance has a negative impact on long-term democratic transition among nondemocratic countries, but oil abundance does not make democratic countries less democratic over time. A significant correlation between oil abundance and defense burden among nondemocratic countries, combined with the lack of positive correlations between oil abundance and various measures of violent challenges to the state, are consistent with the hypothesis that expanding of military capacity is an effective way to deter political challengers in nondemocratic oil-rich countries.

Our findings add to the well-known but controversial literature on the "natural resource curse," which contends that richness in natural resources leads to negative economic and political outcomes. The resource curse doctrine argues that natural resource wealth is an obstacle to economic and political development and hence to overcome it, well-designed resource wealth

\footnotetext{
${ }^{41}$ Aslaksen and Torvik (2006) study how resource abundance affects the choice between conflict and democracy. They also conclude that resource wealth makes conflicts more likely.

${ }^{42}$ Motivated by the observation that poor countries are much more likely to have civil wars than rich ones, on the other hand, Fearon (2007) argues that higher income means that there is not only more rent to appropriate, but also more rent worth defending. Because the marginal costs of staffing a rebel or government force will be greater in a richer country, his model predicts that government and rebel force levels are independent of the size of the appropriable rent. However, there is typically no decision to fight in Fearon's and other earlier models, because arming and fighting are not distinguished. Moreover, these models are static and with a fixed number of players (two, in particular). Tsui (2009) considers an endogenous entry model that distinguishes the impact of resource wealth on the level of force (measured by the expenditure on blocking entry) from the incident of violent challenges to the state (measured by the number of insurgent groups).
} 
management is necessary. This is the rationale behind the World Bank's Chad-Cameroon Petroleum Development and Pipeline Project (Pegg, 2006). Our analysis challenges the popular view that oil resources are necessarily a social curse because oil "fuels" separatism and causes political violence and instability, although we find that oil resources increase the defense burden of nondemocratic countries. ${ }^{43}$ If natural resources themselves are not to blame for various disappointing political outcomes, some of the policy solutions designed to help resource-rich countries escape the "resource curse" may need to be re-evaluated.

${ }^{43}$ Cotet and Tsui (2009) find that oil abundance is not an economic curse either, although oil-rich countries experience higher population growth. 


\section{References}

Acemglu, Daron. "Theory, General Equilibrium, Political Economy and Empirics in Development Economics.” Manuscript, MIT, 2009.

Angrist, Joshua D. and Adriana D. Kugler. "Rural Windfall or a New Resource Curse? Coca, Income, and Civil Conflict in Colombia." Review of Economics and Statistics. 90(2), May 2008: $191-215$

Besley, Timothy J. and Torsten Persson. "The Incidence of Civil War: Theory and Evidence." NBER Working Paper No. w14585. December 2008.

Bohn, Henning and Robert T. Deacon. "Ownership Risk, Investment, and the Use of Natural Resources.” American Economic Review. 90(3), June 2000: 526-549.

BP Statistical Review of World Energy 2007. London: BP p.1.c., 2007.

Brown, James R., Lauren C. Lax, and Bruce C. Peterson. "Financial Market Crises and Natural Resource Production.” Manuscript, Washington University in St. Louis, 2009.

Brunnschweiler, Christa N. and Erwin H. Bulte "Natural Resources and Violent Conflict: Resource Abundance, Dependence and the Onset of Civil Wars." Oxford Economic Papers. 61(4), October 2009: 651-674.

Campbell, Colin J. ASPO Oil Depletion Model, Association for the Study of Peak Oil, 2004.

Collier, Paul and Anke Hoeffler. "On Economic Causes of Civil War." Oxford Economic Papers. 50, 1998: 563-573.

Collier, Paul and Anke Hoeffler. "Greed and Grievance in Civil War." Oxford Economic Papers. 56(4), October 2004: 563-595.

Collier, Paul, Anke Hoeffler, and Måns Söderbom. "On the Duration of Civil War.” Journal of Peace Research. 41(3), May, 2004: 253-273.

Cotet, Anca M. and Kevin K. Tsui. "Resource Curse or Malthusian Trap? Evidence from Oil Discoveries and Extractions." Manuscript, Clemson University, 2009.

David, Paul A. and Gavin Wright. "Increasing Returns and the Genesis of American Resource Abundance." Industrial and Corporate Change. 6(2), March 1997: 203-45.

Davis, Graham A. and Robert D. Cairns. "Valuing Petroleum Reserves Using Current Net Price.” Economic Inquiry. 37(2), April 1999: 295-311.

Dehejia, Rajeev H. and Sadek Wahba. "Causal Effects in Nonexperimental Studies: Reevaluating the Evaluation of Training Programs." Journal of the American Statistical Association. 94(448), December 1999: 1053-1062.

Drew, Lawrence J. "Analysis of the Rate of Wildcat Drilling and Deposit Discovery." Mathematical Geology. 7(5-6), December 1975: 395-414. 
Dube, Oeindrilla and Juan F. Vargas. "Commodity Price Shocks and Civil Conflict: Evidence from Colombia.” Manuscript, NYU, 2009.

Fearon, James D. "Primary Commodity Exports and Civil War." Journal of Conflict Resolution. 49(4), August 2005, 483-507.

Fearon, James D. "Economic Development, Insurgency, and Civil War." in Elhanan Helpman, ed., Institutions and Economic Performance. Cambridge: Harvard University Press, 2007.

Fearon, James D. and David Laitin. "Ethnicity, Insurgency, and Civil War." American Political Science Review. 97(1), February 2003, 75-90.

Field, Erica, Matthew Levinson, Rohini Pande, and Sujata Visaria. "Segregation, Rent Control, and Riots: The Economics of Religious Conflict in an Indian City." American Economic Review. 98(2), 2008: 505--10.

Gerrard, John. "What is a Mountain? Background Paper to Definition of Mountains and Mountain Regions.” Mimeo, Development Economics Research Group, World Bank, 2000.

Gershenson, Dmitriy and Herschel I. Grossman. "Civil Conflict: Ended or Never Ending?" Journal of Conflict Resolution. 44(6), December 2000: 807-821

Gleditsch, Kristian Skrede. "A Revised List of Wars Between and Within Independent States, 1816-2002." International Interactions. 30(3), 2004: 231-262 Data available at http://privatewww.essex.ac.uk/ ksg/expwar.html.

Goemans, Hein, Kristian Gleditsch and Giacomo Chiozza. "Archigos: A Database of Leaders 1875-2004." http://mail.rochester.edu/ hgoemans/data, 2008.

Grossman, Herschel I. "Distributional Disputes and Civil Conflict." Cuadernos de Economía. 40(121), December 2003: 608-616.

Hegre, Håvard and Nicholas Sambanis. "Sensitivity Analysis of Empirical Results on Civil War Onset." Journal of Conflict Resolution. 50(4), August 2006: 508-535.

Hirshleifer, Jack. "The Analytics of Continuing Conflict.” Synthese.76, August 1988: 201--233.

Humphreys, Macartan. "Natural Resources, Conflict, and Conflict Resolution." Journal of Conflict Resolution. 49(4), August 2005: 508-537.

Humphreys, Macartan, Jeffrey D. Sachs, and Joseph E. Stiglitz. Escaping the Resource Curse. Columbia University Press, 2007.

Jones, Benjamin F. and Benjamin A. Olken. "Hit or Miss? The Effect of Assassinations on Institutions and War." American Economic Journal: Macroeconomics. 1(2), July 2009: 55-87.

Laherrere, Jean. "Development Ratio Evolves as True Measure of Exploitation - Evaluating Oil and Gas Reserves." World Oil. February 1998: 117-120.

Laherrere, Jean. "Estimates of Oil Reserves." presented at the International Institute for Applied Systems Analysis, June 19, 2001. 
Maddison, Angus. Statistics on World Population, GDP and Per Capita GDP, 1-2006 AD. http://www.ggdc.net/maddison/

Marshall, Monty G. and Donna Ramsey Marshall. Coups d'Etat, 1960-2006. Center for Systemic Peace. Available at http://www.systemicpeace.org/inscr/inscr.htm

Marshall, Monty G. and Jaggers Keith. Polity IV Project. Center for International Development and Conflict Management, University of Maryland, 2007.

Miguel, Edward. "Poverty and Witch Killing." Review of Economic Studies. 72(4), 2005: 11531172.

Miguel, Edward, Shanker Satyanath, and Ernest Sergenti. "Economic Shocks and Civil Conflict: An Instrumental Variables Approach.” Journal of Political Economy. 112(4), August 2004: 725753.

Miller, Merton H. and Charles W. Upton. "A Test of the Hotelling Valuation Principle." Journal of Political Economy. 93(1), February 1985: 1-25.

Montalvo, José G. and Marta Reynal-Querol. "Ethnic Polarization, Potential Conflict, and Civil Wars." American Economic Review. 95(3), June 2005: 796-816.

Mulligun, Casey B., Ricard Gil, and Xavier Sala-i-Martin. "Do Democracies Have Different Public Policies than Nondemocracies?" Journal of Economic Perspectives. 18(1), Winter 2004: 51-74.

Oster, Emily. "Witchcraft, Weather and Economic Growth in Renaissance Europe." Journal of Economic Perspectives. 18(1), Winter 2004: 215-228.

Pegg, Scott. "Can Policy Intervention Beat the Resource Curse? Evidence from the ChadCameroon Pipeline Project.” African Affairs. 105(418), July 2006: 1-25.

Raleigh, Clionadh and Håvard Hegre. "Population Size, Concentration, and Civil War. A Geographically Disaggregated Analysis.” Political Geography. 28(4), May 2009: 224-238.

Robinson, James A., Ragnar Torvik, and Thierry Verdier. "Political Foundations of the Resource Curse." Journal of Development Economics. 79(2), April 2006: 447-468.

Ross, Michael L. "What Do We Know About Natural Resources and Civil War?" Journal of Peace Research. 41(3), 2004: 337-356.

Ross, Michael L. "A Closer Look at Oil, Diamonds, and Civil War.” Annual Review of Political Science. 9, June 2006: 265-300.

Sambanis, Nicholas. "What Is A Civil War? Conceptual and Empirical Complexities of an Operational Definition." Journal of Conflict Resolution. 48 (6), December 2004: 814-858.

SIPRI military expenditure database. Available at http://www.sipri.org/contents/milap/milex/mex_database1.html 
Smith, Benjamin. "Oil Wealth and Regime Survival in the Developing World, 1960-1999." American Journal of Political Science. 48(2), April 2004: 232-246.

Tsui, Kevin K. "More Oil, Less Democracy: Evidence from Worldwide Crude Oil Discoveries." Economic Journal. forthcoming.

Tsui, Kevin K. "Resource Curse, Political Entry, and Deadweight Costs." Manuscript, Clemson University, 2009.

Tullock, Gordon. Autocracy. Boston, MA: Kluwer Academic Publishers, 1987.

UCDP/PRIO Armed Conflict Dataset. Version 4-2007. Available at http://www.prio.no/CSCW/Datasets/Armed-Conflict/UCDP-PRIO/ 
Table 1: Descriptive Statistics

\begin{tabular}{|c|c|c|c|c|c|}
\hline - & $\begin{array}{l}\text { All } \\
(1)\end{array}$ & $\begin{array}{l}\text { No Oil } \\
\text { (2) }\end{array}$ & $\begin{array}{c}\text { Small Oil } \\
\text { Reserves } \\
(3)\end{array}$ & $\begin{array}{c}\text { Large Oil } \\
\text { Reserves } \\
(4)\end{array}$ & $\begin{array}{c}\text { F-Statistics } \\
\text { (5) }\end{array}$ \\
\hline & \multicolumn{5}{|c|}{ Panel A. Oil Abundance Measures } \\
\hline \multirow[t]{2}{*}{$\log ($ oil reserves per capita) / 100} & -0.120 & -0.207 & -0.060 & -0.018 & $549.68^{* * *}$ \\
\hline & $(0.095)$ & $(0.000)$ & $(0.053)$ & $(0.066)$ & \\
\hline \multirow[t]{3}{*}{$\log$ (oil discovery per capita) / 100} & -0.174 & -0.228 & -0.137 & -0.111 & $219.97^{* * *}$ \\
\hline & $(0.081)$ & $(0.000)$ & $(0.078)$ & $(0.093)$ & \\
\hline & \multicolumn{5}{|c|}{ Panel B. Political Violence Measures } \\
\hline \multirow[t]{2}{*}{ Intense war incidence, Gleditsch-COW } & 0.057 & 0.047 & 0.068 & 0.064 & 0.46 \\
\hline & $(0.231)$ & $(0.213)$ & $(0.252)$ & $(0.244)$ & \\
\hline \multirow[t]{2}{*}{ All conflict incidence, UCDP/PRI } & 0.122 & 0.088 & 0.170 & 0.140 & 1.80 \\
\hline & $(0.327)$ & $(0.284)$ & $(0.376)$ & $(0.347)$ & \\
\hline \multirow[t]{2}{*}{ Intense war onset, Gleditsch-COW } & 0.012 & 0.008 & 0.014 & 0.015 & 1.72 \\
\hline & $(0.107)$ & $(0.091)$ & $(0.119)$ & $(0.122)$ & \\
\hline \multirow[t]{2}{*}{ All Conflict onset, UCDP/PRIO } & 0.027 & 0.023 & 0.032 & 0.028 & 0.69 \\
\hline & $(0.161)$ & $(0.150)$ & $(0.177)$ & $(0.165)$ & \\
\hline \multirow[t]{2}{*}{ Coup attempts } & 0.096 & 0.105 & 0.075 & 0.100 & 0.64 \\
\hline & $(0.359)$ & $(0.362)$ & $(0.334)$ & $(0.376)$ & \\
\hline \multirow[t]{2}{*}{ Irregular leader transitions } & 0.227 & 0.241 & 0.226 & 0.204 & 0.19 \\
\hline & $(0.327)$ & $(0.336)$ & $(0.325)$ & $(0.312)$ & \\
\hline \multirow[t]{3}{*}{ Log (defense burden) } & 0.610 & 0.283 & 0.838 & 1.034 & $2.93^{*}$ \\
\hline & $(1.412)$ & $(1.829)$ & $(0.418)$ & $(0.933)$ & \\
\hline & \multicolumn{5}{|c|}{ Panel C. Other Country Characteristics and Control Variables } \\
\hline \multirow[t]{2}{*}{ Log (GDP per capita) } & 7.830 & 7.376 & 8.038 & 8.492 & $13.85^{* * * *}$ \\
\hline & $(1.078)$ & $(0.958)$ & $(0.965)$ & $(1.012)$ & \\
\hline \multirow[t]{2}{*}{ Economic growth rate } & 1.688 & 1.438 & 2.282 & 1.492 & $7.75^{* * *}$ \\
\hline & (6.133) & (5.522) & (5.655) & (7.605) & \\
\hline \multirow[t]{2}{*}{ Log (population) } & 8.839 & 8.060 & 10.243 & 8.751 & $26.29^{* * *}$ \\
\hline & $(1.569)$ & (1.106) & $(1.374)$ & $(1.876)$ & \\
\hline \multirow[t]{2}{*}{ Log (population density) } & 3.375 & 3.438 & 3.816 & 2.751 & $4.22^{* *}$ \\
\hline & $(1.569)$ & $(1.640)$ & $(1.390)$ & $(1.418)$ & \\
\hline \multirow[t]{2}{*}{ Democracy } & 0.507 & 0.495 & 0.585 & 0.433 & 1.55 \\
\hline & $(0.372)$ & $(0.357)$ & $(0.360)$ & $(0.397)$ & \\
\hline \multirow[t]{2}{*}{ Log (mountainous) } & -0.278 & -0.914 & 1.541 & -0.850 & $3.57^{* *}$ \\
\hline & $(5.023)$ & $(5.256)$ & $(3.441)$ & $(5.434)$ & \\
\hline \multirow[t]{2}{*}{ Ethnic fractionalization } & 0.478 & 0.510 & 0.369 & 0.523 & $3.05^{*}$ \\
\hline & $(0.267)$ & $(0.267)$ & $(0.262)$ & $(0.240)$ & \\
\hline \multirow[t]{2}{*}{ Religious fractionalization } & 0.421 & 0.429 & 0.405 & 0.424 & 0.09 \\
\hline & $(0.244)$ & $(0.248)$ & $(0.235)$ & 0.245 & \\
\hline \multirow[t]{2}{*}{ Language fractionalization } & 0.405 & 0.463 & 0.309 & 0.389 & $2.39^{*}$ \\
\hline & $(0.299)$ & $(0.313)$ & $(0.282)$ & $(0.260)$ & \\
\hline \multirow[t]{2}{*}{ British legal origin } & 0.320 & 0.373 & 0.269 & 0.269 & 0.63 \\
\hline & $(0.467)$ & $(0.484)$ & $(0.444)$ & $(0.444)$ & \\
\hline \multirow[t]{2}{*}{ Wildcat } & 55.251 & 0.000 & 17.751 & 209.136 & $18.34^{* * *}$ \\
\hline & $(514.563)$ & $(0.000)$ & $(27.673)$ & $(1030.142)$ & \\
\hline Number of Countries & 103 & 51 & 26 & 26 & \\
\hline
\end{tabular}


Table 2: Oil Reserves and Civil Conflict Onset

\begin{tabular}{|c|c|c|c|c|c|c|c|}
\hline & & & All Countries & & & $\begin{array}{c}\text { Democratic } \\
\text { Countries } \\
\text { Only } \\
\end{array}$ & $\begin{array}{c}\text { Nondemocratic } \\
\text { Countries } \\
\text { Only } \\
\end{array}$ \\
\hline & $\begin{array}{l}\text { Probit } \\
\text { (1) }\end{array}$ & $\begin{array}{l}\text { Pooled OLS } \\
\text { (2) }\end{array}$ & $\begin{array}{c}\text { Fixed Effects } \\
\text { OLS } \\
\text { (3) }\end{array}$ & $\begin{array}{l}\text { Pooled OLS } \\
\text { (4) }\end{array}$ & $\begin{array}{c}\text { Fixed Effects } \\
\text { OLS } \\
(5)\end{array}$ & $\begin{array}{c}\text { Fixed Effects } \\
\text { OLS } \\
\text { (6) }\end{array}$ & $\begin{array}{c}\text { Fixed Effects } \\
\text { OLS } \\
\text { (7) }\end{array}$ \\
\hline $\begin{array}{l}\text { Log (Oil reserves per capita) / } \\
100\end{array}$ & $\begin{array}{l}0.040^{* *} \\
(0.020)\end{array}$ & $\begin{array}{l}0.076^{* *} \\
(0.033)\end{array}$ & $\begin{array}{c}0.020 \\
(0.054)\end{array}$ & $\begin{array}{l}0.116^{* *} \\
(0.048)\end{array}$ & $\begin{array}{l}0.058 \\
(0.072)\end{array}$ & $\begin{array}{c}0.040 \\
(0.051)\end{array}$ & $\begin{array}{c}0.055 \\
(0.241)\end{array}$ \\
\hline Log (GDP per capita) & $\begin{array}{l}-0.006^{* * * *} \\
(0.002)\end{array}$ & $\begin{array}{l}-0.011^{* * * *} \\
(0.003)\end{array}$ & $\begin{array}{l}-0.006 \\
(0.005)\end{array}$ & $\begin{array}{c}-0.017^{* * * *} \\
(0.004)\end{array}$ & $\begin{array}{l}-0.012 \\
(0.009)\end{array}$ & $\begin{array}{l}-0.001 \\
(0.009)\end{array}$ & $\begin{array}{l}-0.012 \\
(0.014)\end{array}$ \\
\hline Economic growth rate & $\begin{array}{c}-0.001^{* * * *} \\
(0.000)\end{array}$ & $\begin{array}{l}-0.002^{* * *} \\
(0.000)\end{array}$ & $\begin{array}{c}-0.002^{* * * *} \\
(0.001)\end{array}$ & $\begin{array}{c}-0.002^{* * *} \\
(0.001)\end{array}$ & $\begin{array}{l}-0.002^{* * * *} \\
(0.001)\end{array}$ & $\begin{array}{l}-0.001 \\
(0.001)\end{array}$ & $\begin{array}{c}-0.002^{* * * *} \\
(0.001)\end{array}$ \\
\hline Log (population) & $\begin{array}{c}0.001 \\
(0.001)\end{array}$ & $\begin{array}{c}0.001 \\
(0.002)\end{array}$ & $\begin{array}{l}0.039^{* * * *} \\
(0.005)\end{array}$ & $\begin{array}{c}0.003 \\
(0.003)\end{array}$ & $\begin{array}{c}0.004 \\
(0.009)\end{array}$ & $\begin{array}{c}0.001 \\
(0.019)\end{array}$ & $\begin{array}{l}0.065^{* * * *} \\
(0.017)\end{array}$ \\
\hline Log (population density) & $\begin{array}{c}0.001 \\
(0.001)\end{array}$ & $\begin{array}{c}0.002 \\
(0.001)\end{array}$ & $\begin{array}{c}-0.035^{* * *} \\
(0.003)\end{array}$ & $\begin{array}{l}0.004^{* *} \\
(0.002)\end{array}$ & $\begin{array}{c}0.009 \\
(0.006)\end{array}$ & $\begin{array}{c}0.001 \\
(0.005)\end{array}$ & $\begin{array}{c}-0.057^{* * *} \\
(0.010)\end{array}$ \\
\hline Democracy & $\begin{array}{l}-0.001 \\
(0.003)\end{array}$ & $\begin{array}{c}0.002 \\
(0.006)\end{array}$ & $\begin{array}{l}-0.001 \\
(0.010)\end{array}$ & $\begin{array}{c}0.016 \\
(0.010)\end{array}$ & $\begin{array}{c}0.026 \\
(0.016)\end{array}$ & $\begin{array}{c}0.026 \\
(0.093)\end{array}$ & $\begin{array}{l}0.209^{* * * *} \\
(0.055)\end{array}$ \\
\hline Log (mountainous) & $\begin{array}{l}0.001^{* * * *} \\
(0.000)\end{array}$ & $\begin{array}{l}0.001^{* * *} \\
(0.000)\end{array}$ & & $\begin{array}{c}0.001 \\
(0.001)\end{array}$ & & & \\
\hline Ethnic fractionalization & $\begin{array}{c}0.000 \\
(0.007)\end{array}$ & $\begin{array}{l}-0.009 \\
(0.011)\end{array}$ & & $\begin{array}{c}0.001 \\
(0.016)\end{array}$ & & & \\
\hline Religious fractionalization & $\begin{array}{c}0.003 \\
(0.005)\end{array}$ & $\begin{array}{c}0.005 \\
(0.010)\end{array}$ & & $\begin{array}{c}-0.037^{* *} \\
(0.016)\end{array}$ & & & \\
\hline Language fractionalization & $\begin{array}{c}0.005 \\
(0.005)\end{array}$ & $\begin{array}{c}0.015 \\
(0.010)\end{array}$ & & $\begin{array}{l}0.047^{\text {*** }} \\
(0.018)\end{array}$ & & & \\
\hline British legal origin & $\begin{array}{c}-0.000 \\
(0.003)\end{array}$ & $\begin{array}{l}-0.000 \\
(0.005)\end{array}$ & & $\begin{array}{l}-0.002 \\
(0.007)\end{array}$ & & & \\
\hline Data source & $\begin{array}{l}\text { Gleditsch- } \\
\text { COW }\end{array}$ & $\begin{array}{l}\text { Gleditsch- } \\
\text { COW }\end{array}$ & $\begin{array}{l}\text { Gleditsch- } \\
\text { COW }\end{array}$ & UCDP/PRIO & UCDP/PRIO & UCDP/PRIO & UCDP/PRIO \\
\hline Observations & 5011 & 5011 & 5011 & 4314 & 4314 & 2054 & 2260 \\
\hline Number of countries & 103 & 103 & 103 & 103 & 103 & 81 & 77 \\
\hline Period & $1930-2003$ & $1930-2003$ & $1930-2003$ & $1946-2003$ & $1946-2003$ & $1946-2003$ & $1946-2003$ \\
\hline
\end{tabular}

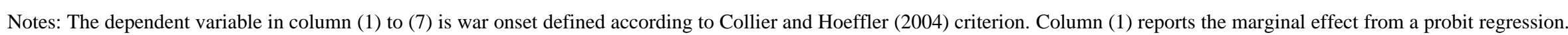

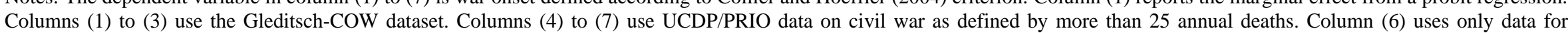

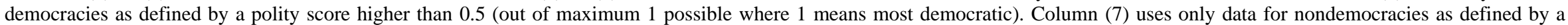
polity score lower or equal to 0.5 . Robust standard errors clustered at the country level are reported in parentheses. * significant at $10 \%$; $* *$ significant at $5 \%$; $* * *$ significant at $1 \%$. 
Table 3: Oil Production and Civil Conflict Onset

\begin{tabular}{|c|c|c|c|c|c|c|}
\hline & $\begin{array}{c}\text { Pooled OLS } \\
\text { (1) }\end{array}$ & $\begin{array}{c}\text { Fixed Effects } \\
\text { OLS } \\
(2) \\
\end{array}$ & $\begin{array}{c}\text { Fixed Effects } \\
\text { 2SLS } \\
(3) \\
\end{array}$ & $\begin{array}{c}\text { Pooled OLS } \\
(4)\end{array}$ & $\begin{array}{c}\text { Fixed Effects } \\
\text { OLS } \\
(5)\end{array}$ & $\begin{array}{c}\text { Fixed Effects } \\
\text { 2SLS } \\
(6) \\
\end{array}$ \\
\hline Log (oil production per capita) / 100 & $\begin{array}{c}0.058^{*} \\
(0.030)\end{array}$ & $\begin{array}{l}-0.023 \\
(0.042)\end{array}$ & $\begin{array}{c}0.024 \\
(0.072)\end{array}$ & $\begin{array}{l}0.087^{* * *} \\
(0.044)\end{array}$ & $\begin{array}{l}-0.037 \\
(0.048)\end{array}$ & $\begin{array}{l}-0.051 \\
(0.086)\end{array}$ \\
\hline First stage $\mathrm{t}$ statistic & & & 6.13 & & & 5.73 \\
\hline Data source & $\begin{array}{l}\text { Gleditsch- } \\
\text { COW }\end{array}$ & $\begin{array}{l}\text { Gleditsch- } \\
\text { COW }\end{array}$ & $\begin{array}{l}\text { Gleditsch- } \\
\text { COW }\end{array}$ & UCDP/PRIO & UCDP/PRIO & UCDP/PRIO \\
\hline Observations & 5011 & 5011 & 4804 & 4314 & 4314 & 4255 \\
\hline Number of countries & 103 & 103 & 103 & 103 & 103 & 103 \\
\hline Period & $1930-2003$ & $1930-2003$ & $1935-2003$ & $1946-2003$ & $1946-2003$ & $1946-2003$ \\
\hline
\end{tabular}

Notes: The dependent variable is war onset defined according to Collier and Hoeffler (2004) criterion. Columns (1) to (3) use the Gleditsch-COW dataset. Columns (4) to (6) use UCDP/PRIO data on civil war as defined by more than 25 annual deaths. All regressions control for Log (GDP per capita), Economic growth rate, Log (population), Log (population density), and Democracy. In addition, columns (1) and (4) also control for Log (mountainous), Ethnic fractionalization, Religious fractionalization, Language fractionalization, and Legal British origin. The instrumental variable is 5 year lag of log oil reserves. Robust standard errors clustered at the country level are reported in parentheses. * significant at $10 \%$; ** significant at $5 \%$; *** significant at $1 \%$. 
Table 4: Oil Reserves and Other Measures of Political Violence

\begin{tabular}{|c|c|c|c|c|c|c|}
\hline & \multicolumn{2}{|c|}{ Coup Attempts } & \multicolumn{2}{|c|}{ Irregular Transitions } & \multicolumn{2}{|c|}{ Defense Burden } \\
\hline & $\begin{array}{c}\text { Pooled } \\
\text { OLS } \\
(1)\end{array}$ & $\begin{array}{l}\text { Fixed } \\
\text { Effects } \\
\text { OLS } \\
(2)\end{array}$ & $\begin{array}{l}\text { Pooled } \\
\text { OLS } \\
(3) \\
\end{array}$ & $\begin{array}{l}\text { Fixed } \\
\text { Effects } \\
\text { OLS } \\
(4) \\
\end{array}$ & $\begin{array}{l}\text { Pooled } \\
\text { OLS } \\
(5) \\
\end{array}$ & $\begin{array}{l}\text { Fixed } \\
\text { Effects } \\
\text { OLS } \\
(6)\end{array}$ \\
\hline Log (oil reserves per capita)/100 & $\begin{array}{c}0.145 \\
(0.139)\end{array}$ & $\begin{array}{l}-0.126 \\
(0.485)\end{array}$ & $\begin{array}{l}\text { Panel A. } \\
0.523^{* * *} \\
(0.234)\end{array}$ & $\begin{array}{c}\text { Countries } \\
0.190 \\
(0.286)\end{array}$ & $\begin{array}{l}2.930^{* *} \\
(1.213)\end{array}$ & $\begin{array}{c}2.572 \\
(15.816)\end{array}$ \\
\hline $\begin{array}{l}\text { Observations } \\
\text { Number of countries } \\
\text { Period }\end{array}$ & $\begin{array}{c}4203 \\
103 \\
1960- \\
2003\end{array}$ & $\begin{array}{c}4203 \\
103 \\
1960- \\
2003\end{array}$ & $\begin{array}{c}3356 \\
98 \\
1930- \\
1984\end{array}$ & $\begin{array}{c}3356 \\
98 \\
1930- \\
1984\end{array}$ & $\begin{array}{c}1395 \\
97 \\
1988- \\
2003\end{array}$ & $\begin{array}{l}1395 \\
97 \\
1988- \\
2003\end{array}$ \\
\hline Log (oil reserves per capita)/100 & $\begin{array}{c}-0.001 \\
(0.090)\end{array}$ & $\begin{array}{l}0.341 \\
(0.388)\end{array}$ & $\begin{array}{l}\text { Democ } \\
0.313 \\
(0.202)\end{array}$ & $\begin{array}{l}\text { Countrie } \\
0.197 \\
(0.188)\end{array}$ & $\begin{array}{c} \\
2.471 \\
(1.718)\end{array}$ & $\begin{array}{l}-21.313 \\
(25.841)\end{array}$ \\
\hline $\begin{array}{l}\text { Observations } \\
\text { Number of countries } \\
\text { Period }\end{array}$ & $\begin{array}{c}1918 \\
81 \\
1960- \\
2003 \\
\end{array}$ & $\begin{array}{c}1918 \\
81 \\
1960- \\
2003 \\
\end{array}$ & $\begin{array}{c}1429 \\
58 \\
1930- \\
1984 \\
\end{array}$ & $\begin{array}{c}1429 \\
58 \\
1930- \\
1984 \\
\end{array}$ & $\begin{array}{c}864 \\
71 \\
1988- \\
2003 \\
\end{array}$ & $\begin{array}{c}864 \\
71 \\
1988- \\
2003 \\
\end{array}$ \\
\hline Log (oil reserves per capita)/100 & $\begin{array}{l}0.454^{*} \\
(0.257)\end{array}$ & $\begin{array}{l}\mathrm{Pa} \\
0.139 \\
(0.963)\end{array}$ & $\begin{array}{l}\text { Nondem } \\
0.717^{* *} \\
(0.353)\end{array}$ & $\begin{array}{l}\text { tic Count } \\
-0.215 \\
(0.552)\end{array}$ & $\begin{array}{l}\text { nly } \\
0.040 \\
(0.890)\end{array}$ & $\begin{array}{l}39.021^{* *} \\
(16.112)\end{array}$ \\
\hline $\begin{array}{l}\text { Observations } \\
\text { Number of countries } \\
\text { Period }\end{array}$ & $\begin{array}{c}2285 \\
75 \\
1960- \\
2003 \\
\end{array}$ & $\begin{array}{c}2285 \\
75 \\
1960- \\
2003 \\
\end{array}$ & $\begin{array}{c}1927 \\
77 \\
1930- \\
1984 \\
\end{array}$ & $\begin{array}{c}1927 \\
77 \\
1930- \\
1984 \\
\end{array}$ & $\begin{array}{c}531 \\
58 \\
1988- \\
2003 \\
\end{array}$ & $\begin{array}{c}531 \\
58 \\
1988- \\
2003 \\
\end{array}$ \\
\hline
\end{tabular}

Notes: Odd numbered columns report the pooled estimated effect of oil reserves on various outcomes as specified, whereas even numbered columns report the fixed-effects estimates. All regressions control for Log (GDP per capita), Economic growth rate, Log (population), Log (population density), and Democracy. Robust standard errors clustered at the country level are reported in parentheses. * significant at $10 \%$; * significant at 5\%; *** significant at $1 \%$. 
Table 5: Are Successful and Failed Oil Exploration Similar?

\begin{tabular}{lccc}
\hline \hline & Success & Failure & Difference \\
& $(1)$ & $(2)$ & $(3)$ \\
\hline Log (oil reserves per capita) / 100 & -0.021 & -0.059 & $0.038^{* * * *}$ \\
& $(0.034)$ & $(0.068)$ & $(0.008)$ \\
Log (GDP per capita) & 8.359 & 8.275 & 0.084 \\
Economic growth rate & $(0.888)$ & $(0.977)$ & $(0.103)$ \\
& 2.240 & 2.167 & 0.073 \\
Log (population) & $(5.852)$ & $(7.169)$ & $(0.330)$ \\
Log (population density) & 9.988 & 9.281 & $0.707^{* * *}$ \\
& $(1.595)$ & $(1.479)$ & $(0.191)$ \\
Democracy & 3.251 & 3.494 & -0.243 \\
Log (mountainous) & $(1.449)$ & $(1.636)$ & $(0.195)$ \\
Ethnic fractionalization & 0.500 & 0.586 & $-0.086^{*}$ \\
& $(0.385)$ & $(0.393)$ & $(0.043)$ \\
Religious fractionalization & 1.183 & 0.137 & $1.046^{*}$ \\
Language fractionalization & $(3.898)$ & $(5.120)$ & $(0.612)$ \\
British legal origin & 0.438 & 0.381 & $0.057^{*}$ \\
Wildcat & $(0.252)$ & $(0.271)$ & $(0.034)$ \\
Observations & 0.387 & 0.423 & -0.036 \\
& $(0.252)$ & $(0.242)$ & $(0.026)$ \\
& 0.299 & 0.282 & 0.017 \\
& 0.269 & 0.242 & 0.032 \\
& 0.249 & 0.271 & -0.021 \\
& 0.433 & 0.445 & 0.050 \\
& 195.150 & 39.727 & 155.423 \\
& $(969.649)$ & $(239.938)$ & $(130.416)$ \\
& 1998 & 600 & 2598 \\
\hline
\end{tabular}

Notes: This table reports the means of each listed variable for the country-years prior to wildcat drilling leading to oil discovery (first column) or failing to lead to oil discovery (second column), with standard deviation reported in parentheses. The last column reports the difference in means. The number of observations represents the number of country-years in which drilling took place. The actual number of observations varies from variable to variable. $*$ significant at $10 \%$;* significant at $5 \%$; *** significant at $1 \%$. 
Table 6: What Predicts Oil Exploration?

\begin{tabular}{lccccc}
\hline \hline & $(1)$ & $(2)$ & $(3)$ & $(4)$ & $(5)$ \\
\hline Log(oil reserves per capita)/100 & $1.476^{* * *}$ & & & & $1.512^{* * *}$ \\
& $(0.083)$ & & & & $(0.090)$ \\
Crude oil price & & $0.003^{* * *}$ & & & $0.001^{* * *}$ \\
& & $(0.000)$ & & & $(0.000)$ \\
Democracy & & & $0.112^{* * *}$ & & $0.176^{* * *}$ \\
& & & $(0.017)$ & & $(0.016)$ \\
War Gleditsch-COW & & & $-0.074^{* * *}$ & $-0.050^{* *}$ \\
& & & & $(0.028)$ & $(0.026)$ \\
Observations & 3081 & 3081 & 3081 & 3081 & 3081 \\
\hline
\end{tabular}

Notes: Results are marginal effects from a logit specification. All independent variables are one year lagged. * significant at $10 \%$; ** significant at 5\%; *** significant at $1 \%$ 
Table 7: Oil Discovery and Violent Challenges to the State

\begin{tabular}{|c|c|c|c|c|}
\hline & \multicolumn{2}{|c|}{ Positive Wildcats Sample } & \multicolumn{2}{|c|}{ Matched Sample } \\
\hline & $\begin{array}{c}\text { Pooled } \\
\text { OLS } \\
(1)\end{array}$ & $\begin{array}{l}\text { Fixed } \\
\text { Effects } \\
\text { OLS } \\
(2) \\
\end{array}$ & $\begin{array}{c}\text { Fixed } \\
\text { Effects } \\
\text { OLS } \\
(3) \\
\end{array}$ & $\begin{array}{c}\text { Fixed } \\
\text { Effects } \\
\text { Matching } \\
(4)\end{array}$ \\
\hline $\log ($ oil discovery per capita)/100 & $\begin{array}{c}\text { Panel A. } \\
0.072 \\
(0.064)\end{array}$ & $\begin{array}{c}\text { ise Civil W } \\
0.072 \\
(0.067)\end{array}$ & $\begin{array}{c}\text { leditsch-( } \\
0.107 \\
(0.067)\end{array}$ & $\begin{array}{c}\text { Dataset) } \\
0.066 \\
(0.066)\end{array}$ \\
\hline Observations & 2378 & 2598 & 3058 & 3058 \\
\hline Number of countries & 52 & 62 & 62 & 62 \\
\hline Log(oil discovery per capita)/100 & $\begin{array}{c}\text { Panel I } \\
0.156^{*} \\
(0.085)\end{array}$ & $\begin{array}{c}\text { Civil Conf } \\
0.141 \\
(0.097)\end{array}$ & $\begin{array}{c}\text { JCDP/PF } \\
0.133 \\
(0.083)\end{array}$ & $\begin{array}{r}\text { Dataset) } \\
0.075 \\
(0.086)\end{array}$ \\
\hline $\begin{array}{l}\text { Observations } \\
\text { Number of countries }\end{array}$ & $\begin{array}{c}2169 \\
52\end{array}$ & $\begin{array}{c}2380 \\
62\end{array}$ & $\begin{array}{c}2734 \\
62\end{array}$ & $\begin{array}{c}2734 \\
62\end{array}$ \\
\hline $\log ($ oil discovery per capita)/100 & $\begin{array}{c}0.104 \\
(0.134)\end{array}$ & $\begin{array}{c}\text { Panel C. C } \\
0.139 \\
(0.138)\end{array}$ & $\begin{array}{c}\text { Attempts } \\
-0.033 \\
(0.181)\end{array}$ & $\begin{array}{l}-0.030 \\
(0.182)\end{array}$ \\
\hline $\begin{array}{l}\text { Observations } \\
\text { Number of countries }\end{array}$ & $\begin{array}{c}1824 \\
52\end{array}$ & $\begin{array}{c}2016 \\
62\end{array}$ & $\begin{array}{c}2254 \\
62\end{array}$ & $\begin{array}{c}2254 \\
62\end{array}$ \\
\hline Log(oil discovery per capita)/100 & $\begin{array}{c} \\
-0.036 \\
(0.139)\end{array}$ & $\begin{array}{c}\text { D. Irregula } \\
0.094 \\
(0.094)\end{array}$ & $\begin{array}{c}\text { der Trans } \\
0.105 \\
(0.109)\end{array}$ & $\begin{array}{l}0.088 \\
(0.106)\end{array}$ \\
\hline $\begin{array}{l}\text { Observations } \\
\text { Number of countries }\end{array}$ & $\begin{array}{c}1506 \\
49\end{array}$ & $\begin{array}{c}1550 \\
51\end{array}$ & $\begin{array}{c}1880 \\
51\end{array}$ & $\begin{array}{c}1880 \\
51\end{array}$ \\
\hline
\end{tabular}

Notes: The positive wildcats sample includes all country-year observations with at least one wildcat drilling. The matched sample is based on all observations (including those with no wildcat drilling) where oil exploration data are available, but only observations whose propensity score belongs to the intersection of the supports of the propensity score of treated and controls were retained. We formed 9 strata for the sample used in the war Gleditsch-COW specification, 11 strata for the war UCDP/PRIO specification, 9 strata for the coup attempts specification, and 7 for the irregular leader transitions specification. All regressions control for lagged log (GDP per capita), lagged economic growth rate, lagged log (population), lagged log (population density), lagged democracy, lagged oil reserves, and the number of wildcats. Robust standard errors clustered at the country level are reported in parentheses. * significant at $10 \%$; ** significant at $5 \%$; *** significant at $1 \%$. 
Table 8: Oil Discovery and Defense Burden

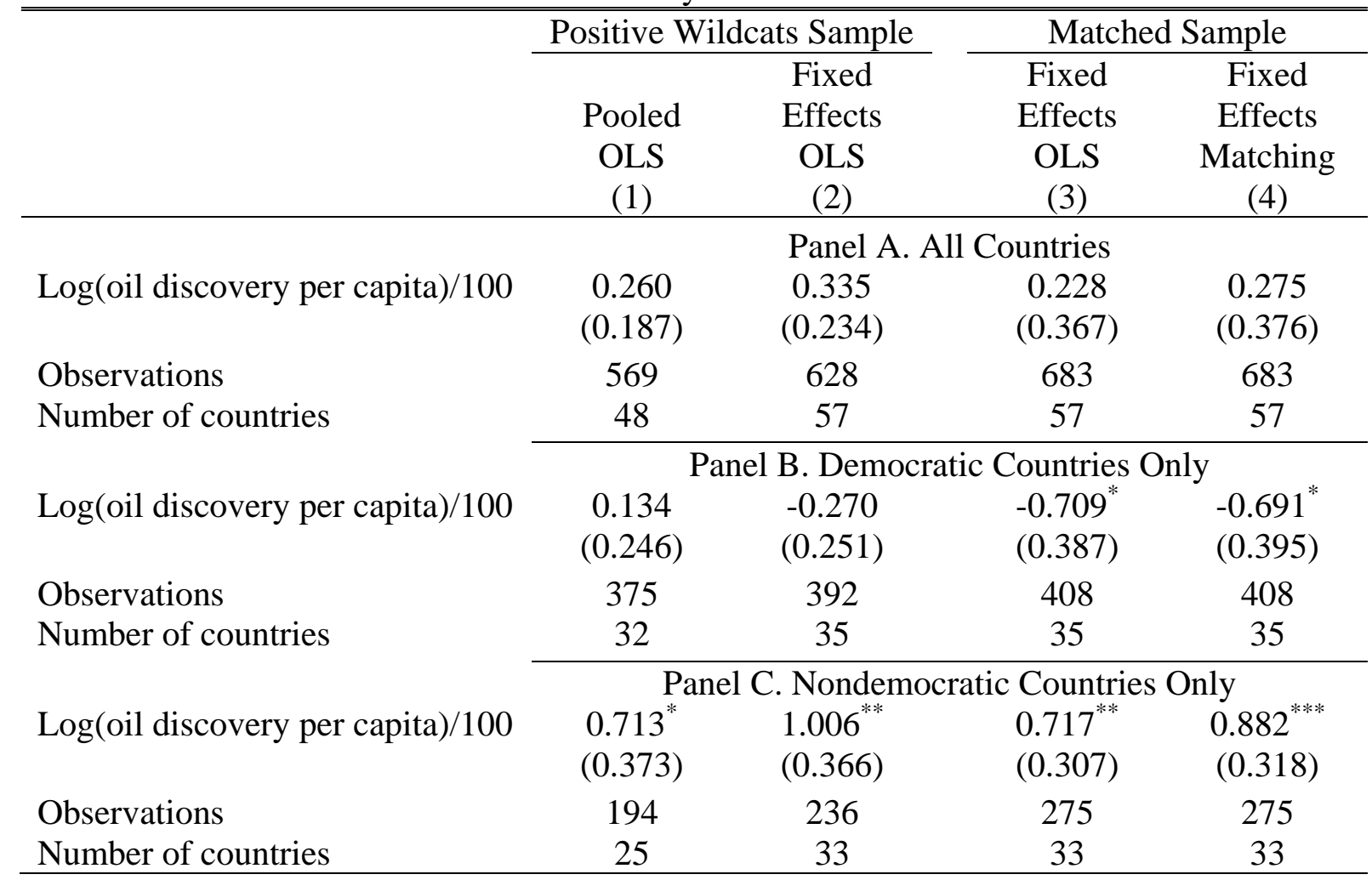

Notes: The positive wildcats sample includes all country-year observations with at least one wildcat drilling. The matched sample is based on all observations (including those with no wildcat drilling) where oil exploration data are available, but only observations whose propensity score belongs to the intersection of the supports of the propensity score of treated and controls were retained. We formed 5 strata for each of the samples used in defense burden specification. All regressions control for lagged log (GDP per capita), lagged economic growth rate, lagged log (population), lagged log (population density), lagged democracy, lagged oil reserves, and the number of wildcats. Robust standard errors clustered at the country level are reported in parentheses. * significant at 10\%; ** significant at 5\%; *** significant at $1 \%$. 
Table 9: Sensitivity Analysis

\begin{tabular}{|c|c|c|c|c|c|c|c|c|c|c|c|c|c|c|}
\hline & \multicolumn{10}{|c|}{ All Countries } & \multicolumn{2}{|c|}{$\begin{array}{c}\text { Democratic } \\
\text { Countries Only }\end{array}$} & \multicolumn{2}{|c|}{$\begin{array}{l}\text { Nondemocratic } \\
\text { Countries Only }\end{array}$} \\
\hline & \multicolumn{2}{|c|}{$\begin{array}{c}\text { Intense Civil } \\
\text { War }\end{array}$} & \multicolumn{2}{|c|}{$\begin{array}{l}\text { All Civil } \\
\text { Conflict }\end{array}$} & \multicolumn{2}{|c|}{ Coup Attempts } & \multicolumn{2}{|c|}{$\begin{array}{l}\text { Irregular Leader } \\
\text { Transitions }\end{array}$} & \multicolumn{6}{|c|}{ Defense Burden } \\
\hline & $(1)$ & $(2)$ & (3) & (4) & $(5)$ & (6) & $(7)$ & $(8)$ & (9) & $(10)$ & $(11)$ & $(12)$ & (13) & $(14)$ \\
\hline Exclude US & $\begin{array}{c}0.027 \\
(0.054)\end{array}$ & $\begin{array}{c}0.069 \\
(0.069)\end{array}$ & $\begin{array}{c}0.066 \\
(0.072)\end{array}$ & $\begin{array}{c}0.144 \\
(0.099)\end{array}$ & $\begin{array}{l}-0.124 \\
(0.485)\end{array}$ & $\begin{array}{c}0.133 \\
(0.140)\end{array}$ & $\begin{array}{c}0.203 \\
(0.287)\end{array}$ & $\begin{array}{c}0.094 \\
(0.093)\end{array}$ & $\begin{array}{c}1.048 \\
(16.224)\end{array}$ & $\begin{array}{c}0.367 \\
(0.239)\end{array}$ & $\begin{array}{l}-26.253 \\
(26.805)\end{array}$ & $\begin{array}{l}-0.244 \\
(0.267)\end{array}$ & $\begin{array}{l}39.021^{* *} \\
(16.112)\end{array}$ & $\begin{array}{l}1.006^{* *} \\
(0.366)\end{array}$ \\
\hline Exclude USSR & $\begin{array}{c}0.020 \\
(0.054)\end{array}$ & $\begin{array}{c}0.072 \\
(0.067)\end{array}$ & $\begin{array}{c}0.058 \\
(0.072)\end{array}$ & $\begin{array}{c}0.151 \\
(0.097)\end{array}$ & $\begin{array}{l}-0.126 \\
(0.485)\end{array}$ & $\begin{array}{c}0.143 \\
(0.137)\end{array}$ & $\begin{array}{c}0.190 \\
(0.286)\end{array}$ & $\begin{array}{c}0.094 \\
(0.094)\end{array}$ & $\begin{array}{c}2.572 \\
(15.816)\end{array}$ & $\begin{array}{c}0.335 \\
(0.234)\end{array}$ & $\begin{array}{l}-21.313 \\
(25.841)\end{array}$ & $\begin{array}{l}-0.270 \\
(0.251)\end{array}$ & $\begin{array}{l}39.021^{* *} \\
(16.112)\end{array}$ & $\begin{array}{l}1.006^{* *} \\
(0.366)\end{array}$ \\
\hline Add Dummy for OPEC & $\begin{array}{c}0.008 \\
(0.053)\end{array}$ & $\begin{array}{c}0.073 \\
(0.067)\end{array}$ & $\begin{array}{c}0.058 \\
(0.072)\end{array}$ & $\begin{array}{c}0.141 \\
(0.097)\end{array}$ & $\begin{array}{l}-0.123 \\
(0.486)\end{array}$ & $\begin{array}{c}0.141 \\
(0.138)\end{array}$ & $\begin{array}{c}0.136 \\
(0.278)\end{array}$ & $\begin{array}{c}0.072 \\
(0.100)\end{array}$ & $\begin{array}{c}2.671 \\
(15.806)\end{array}$ & $\begin{array}{c}0.338 \\
(0.234)\end{array}$ & $\begin{array}{l}-21.000 \\
(25.673)\end{array}$ & $\begin{array}{l}-0.261 \\
(0.251)\end{array}$ & $\begin{array}{l}39.021^{* *} \\
(16.112)\end{array}$ & $\begin{array}{l}1.006^{\text {** }} \\
(0.366)\end{array}$ \\
\hline Low Income Countries & $\begin{array}{c}0.092 \\
(0.240)\end{array}$ & $\begin{array}{c}0.116 \\
(0.172)\end{array}$ & $\begin{array}{l}-0.104 \\
(0.234)\end{array}$ & $\begin{array}{c}0.111 \\
(0.219)\end{array}$ & $\begin{array}{l}-0.273 \\
(0.886)\end{array}$ & $\begin{array}{c}0.093 \\
(0.254)\end{array}$ & $\begin{array}{l}-0.199 \\
(0.847)\end{array}$ & $\begin{array}{c}0.144 \\
(0.174)\end{array}$ & $\begin{array}{c}-3.080 \\
(16.484)\end{array}$ & $\begin{array}{c}0.264 \\
(0.491)\end{array}$ & $\begin{array}{l}-61.372 \\
(40.040)\end{array}$ & $\begin{array}{l}-0.825 \\
(0.805)\end{array}$ & $\begin{array}{l}27.070^{*} \\
(13.760)\end{array}$ & $\begin{array}{l}1.057^{*} \\
(0.579)\end{array}$ \\
\hline Mountainous Countries & $\begin{array}{l}-0.002 \\
(0.047)\end{array}$ & $\begin{array}{c}0.040 \\
(0.097)\end{array}$ & $\begin{array}{l}-0.040 \\
(0.081)\end{array}$ & $\begin{array}{c}0.013 \\
(0.153)\end{array}$ & $\begin{array}{c}-0.046 \\
(0.706)\end{array}$ & $\begin{array}{c}0.219 \\
(0.164)\end{array}$ & $\begin{array}{c}0.250 \\
(0.375)\end{array}$ & $\begin{array}{c}0.133 \\
(0.124)\end{array}$ & $\begin{array}{l}-13.534 \\
(25.353)\end{array}$ & $\begin{array}{c}0.236 \\
(0.266)\end{array}$ & $\begin{array}{l}-39.560 \\
(41.959)\end{array}$ & $\begin{array}{c}-0.316 \\
(0.306)\end{array}$ & $\begin{array}{c}35.526 \\
(29.907)\end{array}$ & $\begin{array}{l}1.215^{\text {*** }} \\
(0.395)\end{array}$ \\
\hline Post WWII & $\begin{array}{c}0.055 \\
(0.071)\end{array}$ & $\begin{array}{c}0.061 \\
(0.069)\end{array}$ & $\begin{array}{c}0.058 \\
(0.072)\end{array}$ & $\begin{array}{c}0.141 \\
(0.097)\end{array}$ & $\begin{array}{l}-0.126 \\
(0.485)\end{array}$ & $\begin{array}{c}0.139 \\
(0.138)\end{array}$ & $\begin{array}{c}0.094 \\
(0.307)\end{array}$ & $\begin{array}{c}0.020 \\
(0.093)\end{array}$ & $\begin{array}{c}2.572 \\
(15.816)\end{array}$ & $\begin{array}{c}0.335 \\
(0.234)\end{array}$ & $\begin{array}{l}-21.313 \\
(25.841)\end{array}$ & $\begin{array}{l}-0.270 \\
(0.251)\end{array}$ & $\begin{array}{l}39.021^{* * *} \\
(16.112)\end{array}$ & $\begin{array}{l}1.006^{* *} \\
(0.366)\end{array}$ \\
\hline No War at (t-1) & $\begin{array}{c}0.022 \\
(0.058)\end{array}$ & $\begin{array}{c}0.042 \\
(0.031)\end{array}$ & $\begin{array}{c}0.081 \\
(0.087)\end{array}$ & $\begin{array}{c}0.085 \\
(0.073)\end{array}$ & $\begin{array}{c}0.019 \\
(0.149)\end{array}$ & $\begin{array}{c}0.204 \\
(0.123)\end{array}$ & $\begin{array}{c}0.060 \\
(0.210)\end{array}$ & $\begin{array}{l}-0.040 \\
(0.095)\end{array}$ & $\begin{array}{c}1.849 \\
(23.456)\end{array}$ & $\begin{array}{c}0.234 \\
(0.236)\end{array}$ & $\begin{array}{c}-1.464 \\
(22.429)\end{array}$ & $\begin{array}{c}-0.304 \\
(0.249)\end{array}$ & $\begin{array}{c}33.212 \\
(29.368)\end{array}$ & $\begin{array}{l}0.695^{\text {** }} \\
(0.297)\end{array}$ \\
\hline Add Time Fixed Effects & $\begin{array}{l}-0.005 \\
(0.054)\end{array}$ & $\begin{array}{c}0.059 \\
(0.063)\end{array}$ & $\begin{array}{c}0.053 \\
(0.067)\end{array}$ & $\begin{array}{c}0.120 \\
(0.098)\end{array}$ & $\begin{array}{l}-0.207 \\
(0.479)\end{array}$ & $\begin{array}{c}0.115 \\
(0.136)\end{array}$ & $\begin{array}{c}0.179 \\
(0.292)\end{array}$ & $\begin{array}{c}0.105 \\
(0.097)\end{array}$ & $\begin{array}{c}-2.493 \\
(18.369)\end{array}$ & $\begin{array}{c}0.248 \\
(0.228)\end{array}$ & $\begin{array}{l}-42.251 \\
(28.865)\end{array}$ & $\begin{array}{l}-0.336 \\
(0.260)\end{array}$ & $\begin{array}{l}39.760^{* *} \\
(16.606)\end{array}$ & $\begin{array}{l}0.938^{* *} \\
(0.387)\end{array}$ \\
\hline Value of Oil & $\begin{array}{c}0.018 \\
(0.052)\end{array}$ & $\begin{array}{c}0.069 \\
(0.066)\end{array}$ & $\begin{array}{c}0.051 \\
(0.068)\end{array}$ & $\begin{array}{c}0.143 \\
(0.098)\end{array}$ & $\begin{array}{l}-0.150 \\
(0.458)\end{array}$ & $\begin{array}{c}0.139 \\
(0.138)\end{array}$ & $\begin{array}{c}0.128 \\
(0.279)\end{array}$ & $\begin{array}{c}0.099 \\
(0.094)\end{array}$ & $\begin{array}{l}-0.213 \\
(9.605)\end{array}$ & $\begin{array}{c}0.342 \\
(0.236)\end{array}$ & $\begin{array}{l}-10.198 \\
(14.249)\end{array}$ & $\begin{array}{l}-0.269 \\
(0.251)\end{array}$ & $\begin{array}{l}19.152^{* * *} \\
(8.627)\end{array}$ & $\begin{array}{c}0.987^{* * * *} \\
(0.351)\end{array}$ \\
\hline
\end{tabular}

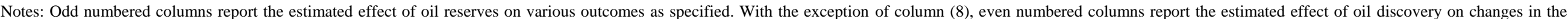

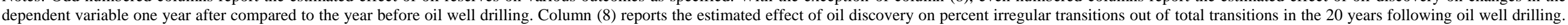

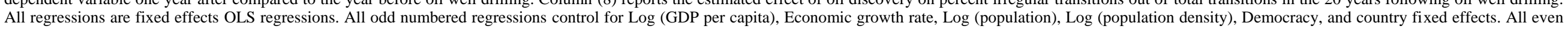

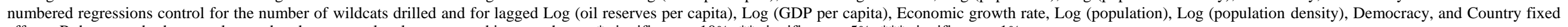
effects. Robust standard errors clustered at the country level are reported in parentheses. * significant at $10 \%$; ** significant at $5 \%$; *** significant at $1 \%$. 
Table 10: Oil Endowment and Political Violence

\begin{tabular}{|c|c|c|c|c|c|}
\hline & $\begin{array}{c}\text { Intense } \\
\text { Civil } \\
\text { War }\end{array}$ & $\begin{array}{c}\text { All } \\
\text { Civil } \\
\text { Conflict }\end{array}$ & $\begin{array}{c}\text { Coup } \\
\text { Attempts }\end{array}$ & $\begin{array}{l}\text { Irregular } \\
\text { Leader } \\
\text { Transitions }\end{array}$ & $\begin{array}{l}\text { Defense } \\
\text { Burden }\end{array}$ \\
\hline & $(1)$ & $(2)$ & $(3)$ & $(4)$ & $(5)$ \\
\hline Log(Oil Endowment/area)/100 & $\begin{array}{c}0.204 \\
(0.326)\end{array}$ & $\begin{array}{c}0.699 \\
(0.423)\end{array}$ & $\begin{array}{c}0.191 \\
(0.211)\end{array}$ & $\begin{array}{c}0.106 \\
(0.459)\end{array}$ & $\begin{array}{l}7.660^{* * *} \\
(3.300)\end{array}$ \\
\hline Log (mountainous) & $\begin{array}{l}0.008^{* * *} \\
(0.002)\end{array}$ & $\begin{array}{l}0.011^{* * *} \\
(0.003)\end{array}$ & $\begin{array}{l}0.004^{* * *} \\
(0.001)\end{array}$ & $\begin{array}{c}0.000 \\
(0.004)\end{array}$ & $\begin{array}{c}-0.023 \\
(0.026)\end{array}$ \\
\hline Ethnic fractionalization & $\begin{array}{c}0.034 \\
(0.080)\end{array}$ & $\begin{array}{c}0.070 \\
(0.112)\end{array}$ & $\begin{array}{c}0.037 \\
(0.048)\end{array}$ & $\begin{array}{c}0.157 \\
(0.110)\end{array}$ & $\begin{array}{c}0.369 \\
(0.679)\end{array}$ \\
\hline Religious fractionalization & $\begin{array}{c}0.012 \\
(0.060)\end{array}$ & $\begin{array}{l}-0.110 \\
(0.080)\end{array}$ & $\begin{array}{l}-0.029 \\
(0.039)\end{array}$ & $\begin{array}{l}-0.079 \\
(0.105)\end{array}$ & $\begin{array}{c}0.469 \\
(0.420)\end{array}$ \\
\hline British legal origin & $\begin{array}{l}-0.009 \\
(0.035)\end{array}$ & $\begin{array}{l}-0.005 \\
(0.050)\end{array}$ & $\begin{array}{l}-0.034 \\
(0.023)\end{array}$ & $\begin{array}{c}-0.204^{* * *} \\
(0.052)\end{array}$ & $\begin{array}{c}0.208 \\
(0.195)\end{array}$ \\
\hline $\begin{array}{l}\text { Observations } \\
\mathrm{R}^{2}\end{array}$ & $\begin{array}{c}120 \\
0.150\end{array}$ & $\begin{array}{c}120 \\
0.256\end{array}$ & $\begin{array}{c}120 \\
0.253\end{array}$ & $\begin{array}{c}113 \\
0.357\end{array}$ & $\begin{array}{c}108 \\
0.202\end{array}$ \\
\hline
\end{tabular}

Notes: Various measures of political violence are averaged over the period since 1960. Oil endowment is the initial oil-in-place, normalized by country's land area. All regressions control for region fixed effects. The six regions, according to the UN classification, are Africa, Central and South America, North America, Asia, Europe, and Oceania. Robust standard errors are reported in parentheses. * significant at $10 \%$; ** significant at $5 \%$; $* * *$ significant at $1 \%$. 